\title{
Hydrogen Production and Enzyme Activities in the Hyperthermophile Thermococcus paralvinellae Grown on Maltose, Tryptone, and Agricultural Waste
}

\author{
Sarah A. Hensley, Emily Moreira and James F. Holden * \\ Department of Microbiology, University of Massachusetts Amherst, Amherst, MA, USA
}

\section{OPEN ACCESS}

Edited by:

Philippe M. Oger,

École Normale Supérieure de Lyon,

France

Reviewed by:

Kesen Ma,

University of Waterloo, Canada

Amy Michele Grunden,

North Carolina State University, USA

Anais Cario,

Rensselaer Polytechnic Institute, USA

*Correspondence:

James F. Holden

jholden@microbio.umass.edu

Specialty section:

This article was submitted to

Extreme Microbiology,

a section of the journal

Frontiers in Microbiology

Received: 19 November 2015

Accepted: 01 February 2016

Published: 23 February 2016

Citation:

Hensley SA, Moreira E and Holden JF (2016) Hydrogen Production and

Enzyme Activities in the Hyperthermophile Thermococcus paralvinellae Grown on Maltose, Tryptone, and Agricultural Waste. Front. Microbiol. 7:167. doi: 10.3389/fmicb.2016.00167
Thermococcus may be an important alternative source of $\mathrm{H}_{2}$ in the hot subseafloor in otherwise low $\mathrm{H}_{2}$ environments such as some hydrothermal vents and oil reservoirs. It may also be useful in industry for rapid agricultural waste treatment and concomitant $\mathrm{H}_{2}$ production. Thermococcus paralvinellae grown at $82^{\circ} \mathrm{C}$ without sulfur produced up to $5 \mathrm{mmol}$ of $\mathrm{H}_{2} \mathrm{~L}^{-1}$ at rates of $5-36 \mathrm{fmol} \mathrm{H}_{2}$ cell $^{-1} \mathrm{~h}^{-1}$ on $0.5 \%$ (wt vol ${ }^{-1}$ ) maltose, $0.5 \%\left(\mathrm{wt} \mathrm{vol}^{-1}\right)$ tryptone, and $0.5 \%$ maltose $+0.05 \%$ tryptone media. Two potentially inhibiting conditions, the presence of $10 \mathrm{mM}$ acetate and low $\mathrm{pH}(\mathrm{pH} 5)$ in maltose-only medium, did not significantly affect growth or $\mathrm{H}_{2}$ production. Growth rates, $\mathrm{H}_{2}$ production rates, and cell yields based on $\mathrm{H}_{2}$ production were the same as those for Pyrococcus furiosus grown at $95^{\circ} \mathrm{C}$ on the same media for comparison. Acetate, butyrate, succinate, isovalerate, and formate were also detected as end products. After $100 \mathrm{~h}$, T. paralvinellae produced up to $5 \mathrm{mmol}$ of $\mathrm{H}_{2} \mathrm{~L}^{-1}$ of medium when grown on up to $70 \%$ ( $\mathrm{vol} \mathrm{vol}^{-1}$ ) waste milk from cows undergoing treatment for mastitis with the bacterial antibiotic Ceftiofur and from untreated cows. The amount of $\mathrm{H}_{2}$ produced by $T$. paralvinellae increased with increasing waste concentrations, but decreased in $P$. furiosus cultures supplemented with waste milk above $1 \%$ concentration. All mesophilic bacteria from the waste milk that grew on Luria Bertani, Sheep's Blood (selective for Staphylococcus, the typical cause of mastitis), and MacConkey (selective for Gram-negative enteric bacteria) agar plates were killed by heat during incubation at $82^{\circ} \mathrm{C}$. Ceftiofur, which is heat labile, was below the detection limit following incubation at $82^{\circ} \mathrm{C}$. T. paralvinellae also produced up to $6 \mathrm{mmol}$ of $\mathrm{H}_{2} \mathrm{~L}^{-1}$ of medium when grown on $0.1-10 \%\left(\mathrm{wt} \mathrm{vol}^{-1}\right)$ spent brewery grain while $P$. furiosus produced $<1 \mathrm{mmol}$ of $\mathrm{H}_{2} \mathrm{~L}^{-1}$. Twelve of 13 enzyme activities in $T$. paralvinellae showed significant $(p<0.05)$ differences across six different growth conditions; however, methyl viologen-dependent membrane hydrogenase activity remained constant across all media types. The results demonstrate the potential of at least some Thermococcus species to produce $\mathrm{H}_{2}$ if protein and $\alpha$-glucosides are present as substrates.

Keywords: hyperthermophile, Thermococcus, hydrogenase, waste remediation, bioenergy 


\section{INTRODUCTION}

Thermococcus species are hyperthermophilic heterotrophic archaea that catabolize carbohydrates and peptides and produce organic acids and $\mathrm{CO}_{2}$ as metabolites (Figure 1; Adams, 1999). Their growth is often associated with sulfur reduction to $\mathrm{H}_{2} \mathrm{~S}$, but in the absence of sulfur some species produce $\mathrm{H}_{2}$ as a major end product (Bálint et al., 2005; Kanai et al., 2005). Based on genome sequence analysis, all Thermococcus species have at least one $\mathrm{NAD}(\mathrm{P}) \mathrm{H}$-dependent cytoplasmic hydrogenase and a ferredoxin (Fd)-dependent membrane hydrogenase that translocates $\mathrm{H}^{+}$or $\mathrm{Na}^{+}$across the membrane. Thermococcus onnurineus also produces $\mathrm{H}_{2}$ using a formate-dependent membrane hydrogenase (Kim et al., 2010; Bae et al., 2012) and a CO-dependent membrane hydrogenase (Kim et al., 2013). Thermococcus paralvinellae produced $\mathrm{H}_{2}$ when grown on both maltose and tryptone $\left(0.5 \% \mathrm{wt} \mathrm{vol}^{-1}\right.$ of each) without sulfur (Hensley et al., 2014). Its complete genome sequence contains seven hydrogenase gene clusters (Jung et al., 2014). Four of these clusters are putatively membrane bound and use ferredoxin, formate and $\mathrm{CO}$ as electron donors coupled with $\mathrm{H}^{+} / \mathrm{Na}^{+}$translocation, and three are cytoplasmic and use $\mathrm{NAD}(\mathrm{P}) \mathrm{H}$ or coenzyme $\mathrm{F}_{420}$ as electron pairs (Figure 1).
However, nothing is known about $\mathrm{H}_{2}$ production kinetics and enzyme activities in $T$. paralvinellae when grown on varying substrates or environmental conditions without sulfur.

Most of what is known about the central metabolism of Thermococcus has been obtained from studying Pyrococcus furiosus (see Adams, 1999; Verhees et al., 2003 for reviews), which like Thermococcus is a member of the Thermococcaceae. Glycolysis in both genera occurs via a modified EmbdenMeyerhof pathway that uses ADP-dependent kinases (Kengen et al., 1994) and glyceraldehyde-3-phosphate:Fd oxidoreductase in lieu of glyceraldehyde-3-phosphate dehydrogenase and phosphoglycerate kinase (Mukund and Adams, 1995). Peptide catabolism occurs via peptide transamination and glutamate dehydrogenase to form 2-keto acids and reduction potential in the form of $\mathrm{NAD}(\mathrm{P}) \mathrm{H}$ (Figure 1; Robb et al., 1992). Pyruvate and other 2-keto acids are oxidized to acetate and other carboxylic acids plus $\mathrm{CO}_{2}$, reduced Fd, and ATP (Blamey and Adams, 1993; Schäfer et al., 1993; Heider et al., 1996; Mai and Adams, 1996). Alternatively, pyruvate can be reduced to alanine (Kengen and Stams, 1994), and the acyl-CoA products can be potentially reduced to alcohols (Basen et al., 2014) if alternative terminal electron acceptors are not available. $T$. paralvinellae produced ethanol and butanol when sulfur was in

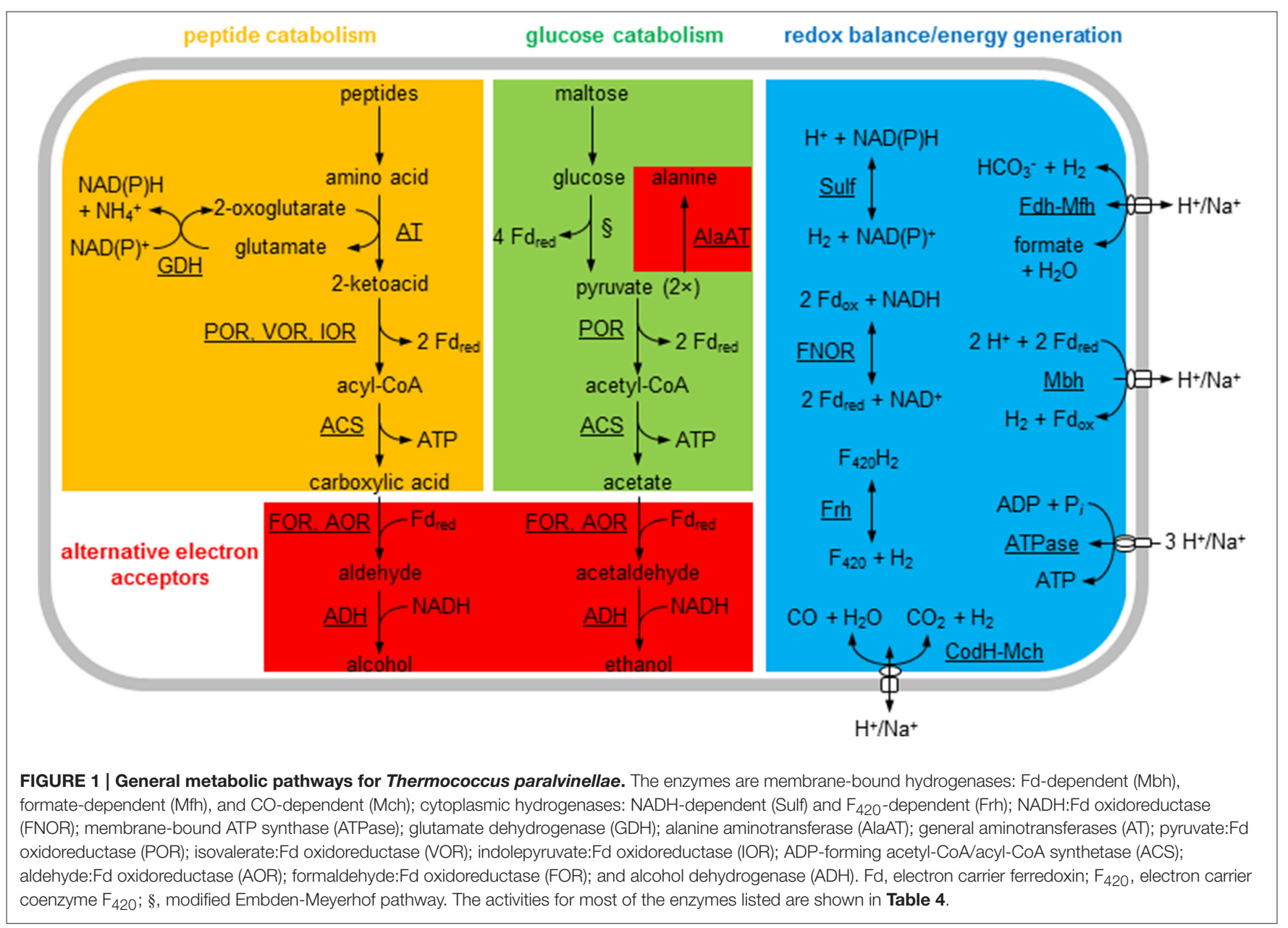


limited supply suggesting that it can also ferment when necessary (Ma et al., 1995).

Hydrogen-producing Thermococcus support the growth of hydrogenotrophic methanogens in the absence of other $\mathrm{H}_{2}$ sources through syntrophy (Bonch-Osmolovskaya and Stetter, 1991; Canganella and Jones, 1994; Davidova et al., 2012; Ver Eecke et al., 2012) and could be an important alternative source of energy in low- $\mathrm{H}_{2}$ environments. Thermococcus could also be used to consolidate wastewater organic compound remediation and heat treatment for pathogen removal in a single step to decrease costs while producing $\mathrm{H}_{2}$ as an energy product (Angenent et al., 2004; Bougrier et al., 2007; Girguis and Holden, 2012). In the U.S., nearly all food and agricultural waste enters landfills, which is the largest contributor of material entering these sites (Staley and Barlaz, 2009; Levis et al., 2010). It is increasingly being diverted to wastewater treatment facilities for anaerobic digestion to limit landfill growth and eutrophication (Diggelman and Ham, 2003; Lai et al., 2009). The waste contains high concentrations of organic compounds and often harmful chemicals such as antibiotics and hormones (Bougrier et al., 2007; Wang and Wan, 2009; Ntaikou et al., 2010) that foul wastewater treatment equipment leading to increasing restrictions on entering waste content (Lee et al., 2007). Biological pre-treatment of large organic molecules by fermentative organisms lowers the high organic carbon load in waste, lowers wastewater treatment costs, and can produce bioenergy to partially offset costs (Angenent et al., 2004; Wang and Wan, 2009; Ntaikou et al., 2010).

While the catabolic and energy generation pathways of $T$. paralvinellae are reasonably well established, its physiology, growth, and $\mathrm{H}_{2}$ production kinetics under normal and potentially adverse growth conditions are poorly understood. In this study, the growth and $\mathrm{H}_{2}$ production rates, the production of other metabolites, and the activities of 13 enzymes were measured from $T$. paralvinellae grown at $82^{\circ} \mathrm{C}$ on maltose, tryptone, and maltose plus tryptone as well as maltose plus acetate and maltose at low $\mathrm{pH}(\mathrm{pH}$ 5) as potentially inhibitory conditions. $P$. furiosus was grown and analyzed in parallel at $95^{\circ} \mathrm{C}$ for comparison. These two organisms were grown for the first time on waste milk from cows treated for mastitis with Ceftiofur or from untreated cows, and separately on spent brewery grain to examine the feasibility of using them to rapidly remediate agricultural wastes. Ceftiofur is a heat-labile $\beta$ lactam that inhibits peptidoglycan synthesis in bacteria (Sunkara et al., 1999). We sought to remove organic compounds during growth and the pathogens and Ceftiofur from the milk by heat treatment during growth of $T$. paralvinellae with concomitant production of $\mathrm{H}_{2}$.

\section{MATERIALS AND METHODS}

\section{Organisms Used}

T. paralvinellae ES1 (DSM 27261) was from our hyperthermophile culture collection. P. furiosus (DSM 3638) was obtained from the Deutsche Sammlung für Mikroorganismen und Zelkulturen (Braunschweig, Germany).

\section{Growth Conditions}

The base medium for growth was from Adams et al. (2001). Different carbon sources were added to the base medium solution, which were $0.5 \%$ (wt $\mathrm{vol}^{-1}$ ) maltose plus $0.01 \%$ (wt $\mathrm{vol}^{-1}$ ) yeast extract (enzymatic, Difco); $0.5 \%\left(\mathrm{wt} \mathrm{vol}^{-1}\right.$ ) tryptone (Difco) plus $0.01 \%$ yeast extract; and $0.5 \%$ maltose, $0.05 \%$ tryptone plus $0.01 \%$ yeast extract. To examine the effect of acetate on cells, $10 \mathrm{mM}$ acetate was added to $0.5 \%$ maltose plus $0.01 \%$ yeast extract medium. To examine growth at low $\mathrm{pH}$, $0.5 \%$ maltose plus $0.01 \%$ yeast extract medium was $\mathrm{pH}$ balanced to $5.00 \pm 0.05$ at room temperature. All other media were $\mathrm{pH}$ balanced to $6.80 \pm 0.05$ at room temperature. For bottle experiments, these media $(20 \mathrm{ml})$ were contained in $60 \mathrm{ml}$ serum bottles with 1 atm of $\mathrm{N}_{2}$ in the headspace. Growth was also tested on $0.5 \%\left(\mathrm{wt} \mathrm{vol}^{-1}\right)$ lactose plus $0.01 \%$ yeast extract in base medium as a follow-up to the waste milk growth experiments described below.

For the waste media experiments, one of three waste types was added as a carbon source to the base medium above. The milk medium contained $0.1,1$, or $10 \%\left(\mathrm{vol} \mathrm{vol}^{-1}\right)$ waste milk obtained fresh from a local dairy farm (Barstow Farms, Hadley, MA). For $T$. paralvinellae, $20,30,50$, and $70 \%$ waste milk were also examined. The milk was from cows with mastitis that had been treated with Ceftiofur within the previous $48 \mathrm{~h}$ and from healthy untreated cows. The grain medium contained $0.1,1$, or $10 \%$ (wt vol-1) spent brewery grain from a local brewery (Amherst Brewing Company, Amherst, MA). The initial chemical oxygen demand (COD) of $10 \%$ waste was $357 \pm 6 \mathrm{~g}^{-1}$ (mean \pm standard error) in milk from untreated cows, $363 \pm 3 \mathrm{~g} \mathrm{l}^{-1}$ in milk from treated cows, and $334 \pm 3 \mathrm{~g} \mathrm{l}^{-1}$ in spent grain waste as determined from a COD HR test kit (Hach Company). Milk and grain that was not used within $12 \mathrm{~h}$ was frozen at $-20^{\circ} \mathrm{C}$. The waste media $(50 \mathrm{ml})$ were contained in $120 \mathrm{ml}$ serum bottles with $1 \mathrm{~atm}$ of $\mathrm{N}_{2}$ in the headspace.

All bottle cultures were incubated in a forced-air oven without stirring at $82^{\circ} \mathrm{C}$ for $T$. paralvinellae and $95^{\circ} \mathrm{C}$ for $P$. furiosus. The serum bottles were inoculated with a logarithmic growthphase culture that had been grown and transferred at least three successive times in bottles on the medium used so that cultures were adapted to that medium. For the maltose-only, tryptone-only, maltose-tryptone, maltose-acetate, and low $\mathrm{pH}$ maltose media experiments, 12 serum bottles were inoculated concurrently and a pair of bottles was removed at different times during growth until the cultures reached stationary growth phase. For the waste media experiments, triplicate bottles were inoculated and subsampled every $12 \mathrm{~h}$ for up to $100 \mathrm{~h}$. Cell concentrations were measured using a Petroff-Hausser counting chamber and phase-contrast light microscopy. The specific growth rate $(\mu)$ of the culture was determined by a best-fit curve through the logarithmic portion of the growth data.

Cultures were also grown in duplicate in a 20 -L bioreactor for each defined media type and for $1 \%$ milk from Ceftiofurtreated cows. The media were flushed with $\mathrm{N}_{2}: \mathrm{CO}_{2} \quad(80: 20 \%)$

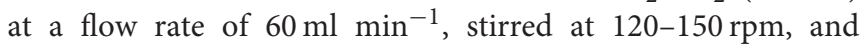
heated to $82 \pm 0.1^{\circ} \mathrm{C}$ for $T$. paralvinellae and $95 \pm 0.1^{\circ} \mathrm{C}$ for $P$. furiosus. $\mathrm{CO}_{2}$ was added to the flushing gas to help offset the $\mathrm{CO}_{2}$ lost from the $\mathrm{NaHCO}_{3}$ in the base medium. With the 
exception of the low $\mathrm{pH}$ condition $(\mathrm{pH} 5.0 \pm 0.1)$, the $\mathrm{pH}$ of the bioreactor media was set at 6.8 at room temperature but rose with temperature to $\mathrm{pH} 7.2$ where it was maintained $( \pm 0.1 \mathrm{pH}$ unit) by the automatic addition of $5 \%\left(\right.$ wt vol ${ }^{-1}$ ) $\mathrm{NaHCO}_{3}$ at the incubation temperature. Cells from the bioreactor were harvested when they reached late logarithmic growth phase. The medium was drained from the bioreactor through a glass cooling coil bathed in an ice-water-slurry into a carboy. The cells were then concentrated to less than $2 \mathrm{~L}$ by ultrafiltration using a hollow fiber cartridge (0.2- $\mu \mathrm{m}$ pore size; Amersham Biosciences) and further concentrated by centrifugation at $10,000 \times g$ for $45 \mathrm{~min}$. The exception was cells grown on the milk due to flocculation in the medium where only centrifugation was used to concentrate the cells. The resulting pellets were resuspended in an anoxic chamber in $<5 \mathrm{ml}$ of degassed $50 \mathrm{mM}$ Tris buffer ( $\mathrm{pH}$ 8.0) plus $2 \mathrm{mM}$ of sodium dithionite (DT), sealed in a $\mathrm{N}_{2}$-flushed serum bottle, and frozen at $-20^{\circ} \mathrm{C}$.

\section{Metabolite Measurements}

Metabolite measurements were only performed on bottle experiments. A subsample $(100 \mu \mathrm{l})$ of headspace from each bottle at each time point was used to measure the amount of $\mathrm{H}_{2}$ present using a gas chromatograph (Shimadzu GC-8A) equipped with a thermal conductivity detector, a 60/80 Carboxen 1000 column (Supelco), and Ar as the carrier gas. Hydrogen yields per cell $\left(Y_{\mathrm{p} / \mathrm{x}}\right)$ were determined by plotting the amount of $\mathrm{H}_{2}$ produced against cell concentrations for each set of time points within a growth curve. Specific $\mathrm{H}_{2}$ production rates $(q)$ were calculated from $\left(Y_{\mathrm{p} / \mathrm{x}} \times \mu\right) / 0.693$, and theoretical maximum $\mathrm{H}_{2}$ production rates $\left(r_{\max }\right)$ were calculated from the product of $q$ times the maximum cell concentration ( $\left(\mathrm{ll}_{\max }\right)$. For defined media experiments, soluble metabolites were measured after $18 \mathrm{~h}$ of incubation. A $1.5 \mathrm{ml}$ aliquot was transferred into an Eppendorf microfuge tube and spun at $14,000 \mathrm{rpm}$ for $5 \mathrm{~min}$. The supernatant was decanted and filtered through a $0.22 \mu \mathrm{m}$ pore size filter (13 mm diameter, GVPP, Millipore) and $100 \mu \mathrm{l}$ of $1 \mathrm{M}$ $\mathrm{H}_{2} \mathrm{SO}_{4}$ was added to $1 \mathrm{ml}$ of filtrate. Samples were run through an Aminex HPX-87H ion exclusion column (300 $\mathrm{mm} \times 7.8 \mathrm{~mm}$, Bio-Rad) with guard column (BioRad microguard Cation $\mathrm{H}$ ) with $5 \mathrm{mM} \mathrm{H}_{2} \mathrm{SO}_{4}$ as the mobile phase using an ultra-pressure liquid chromatography (UPLC) system (Shimadzu) equipped with a refractive index detector. The column was kept at $30^{\circ} \mathrm{C}$ with a $0.6 \mathrm{ml} \mathrm{min}^{-1}$ flow rate and a $30 \mathrm{~min}$ sampling time.

\section{Waste Remediation}

To determine which portion of the milk waste was degraded during growth, $1 \%$ waste milk from Ceftiofur treated cows and untreated cows were inoculated separately with each organism and incubated as before along with uninoculated triplicate controls. A $1.5 \mathrm{ml}$ liquid subsample was removed from each serum bottle every $12 \mathrm{~h}$ for soluble protein and reducing sugar measurements. For protein measurements, $1 \mathrm{ml}$ of sample was filtered through a $0.22 \mu \mathrm{m}$ pore size filter $(13 \mathrm{~mm}$ diameter, GVPP, Millipore) and the protein in the filtrate was measured using a protein assay kit (Bio-Rad). For the reducing sugar measurements, $0.5 \mathrm{ml}$ of sample and $0.5 \mathrm{ml}$ of dinitrosalicylic acid solution (DNS) were heated to $100^{\circ} \mathrm{C}$ for $5 \mathrm{~min}$, cooled in ice for
$5 \mathrm{~min}$, and then absorbance measured at $545 \mathrm{~nm}$ with lactose used as standard. The DNS was composed of the following (per liter): $7.06 \mathrm{~g}$ of 3,5-dinitrosalicylic acid, $13.2 \mathrm{~g}$ of sodium hydroxide, $204 \mathrm{~g}$ of Rochelle salt, $5.53 \mathrm{~g}$ of sodium metabisulfite, and $5.06 \mathrm{ml}$ phenol (boiled). Uninoculated controls determined if indigenous microbes were affecting waste content or $\mathrm{H}_{2}$ production.

To determine if pathogens were removed from the milk, $1 \%$ waste milk from Ceftiofur-treated cows and untreated cows that was less than $48 \mathrm{~h}$ old, as well as base medium without an added carbon source, were plated via a dilution-to-extinction method onto Luria Bertani, Sheep's Blood, and MacConkey agar plates both prior to and after $100 \mathrm{~h}$ of incubation with T. paralvinellae at $82^{\circ} \mathrm{C}$ and were incubated up to 2 days at $37^{\circ} \mathrm{C}$. Sheep's Blood agar is selective for Gram-positive bacteria, the most common causative agent of bovine mastitis, and MacConkey agar is selective for Gram-negative enteric bacteria, which are another source of mastitis. Technical triplicates of each media, time point, and agar plate type were run. The number of colony forming units per $\mathrm{ml}$ of inoculum was determined for all plates. To determine if Ceftiofur was present in waste milk, samples of undiluted waste milk from treated cows and samples of $10 \%$ milk media before and after $100 \mathrm{~h}$ of incubation at $82^{\circ} \mathrm{C}$ with and without inoculation with T. paralvinellae were tested using a Ceftiofur ELISA Test Kit (Bioo Scientific) as described by the manufacturer.

\section{Protein Fractionation}

All sample transfers and manipulations were carried out in an anoxic chamber and buffers were degassed with $\mathrm{N}_{2}$. Stored frozen cells were allowed to warm to room temperature and $2 \mu \mathrm{g} \mathrm{ml}^{-1}$ of DNase I were added. The cell suspension was mixed for $30 \mathrm{~min}$. The sample vial was then placed in an ice-water slurry and sonicated for $30 \mathrm{~min}$ (Fisher Scientific, Sonic Dismembrator 500). Phase-contrast microscopy confirmed cell lysis. The cell suspension was spun in a centrifuge at $100,000 \times g$ for $45 \mathrm{~min}$. The supernatant was removed as the soluble protein fraction and the pellet was resuspended in buffer after being homogenized with a glass tissue grinder. The suspension was spun at 100,000 $\times$ $g$ for $45 \mathrm{~min}$ as before and resuspended three times to wash the pellet. After the final spin, the pellet was resuspended in $1 \mathrm{ml}$ of buffer. This was used as the insoluble protein fraction. The protein concentrations of the soluble protein fractions were determined spectrophotometrically using a protein assay kit (Bio-Rad). The protein concentrations of the insoluble protein fractions were determined using the DC Protein Assay kit (BioRad). Bovine serum albumin was used as the standard for both procedures. Protein fractions that were not used immediately for enzyme activity assays were flash frozen in liquid $\mathrm{N}_{2}$ and stored at $-80^{\circ} \mathrm{C}$.

\section{Enzyme Assays}

Enzyme activities are expressed as units where $1 \mathrm{U}$ is equal to $1 \mu \mathrm{mol}$ of substrate transformed $\mathrm{min}^{-1}$. The buffer used for all assays was $100 \mathrm{mM}$ EPPS buffer $(\mathrm{pH}$ 8.4) and the assay temperature was $80^{\circ} \mathrm{C}$, unless otherwise noted. At least three technical replicates were run for each assay. For enzyme assays containing benzyl viologen (BV) or methyl viologen (MV), a 
trace amount of $2 \mathrm{mM}$ sodium dithionite (DT) was added to slightly reduce the buffer. The amount of all reagents used is given as the final concentration in the reaction vial.

The following anaerobic enzyme activity assays were performed using the insoluble protein fraction and were contained in rubber stopper-sealed serum vials ( $8 \mathrm{ml}$ volume) that had been degassed and flushed with $\mathrm{N}_{2}$. Membrane-bound hydrogenase (Mbh) (Sapra et al., 2000) activity was determined by following the $\mathrm{H}_{2}$ evolution rate in a discontinuous assay using $3 \mathrm{mM}$ MV reduced with $30 \mathrm{mM}$ DT as the electron donor. $\mathrm{H}_{2}$ was measured by gas chromatography as described above. Membrane-bound ATP synthase (ATPase) (Pisa et al., 2007) activity was determined by following the phosphate evolution rate in a discontinuous assay by adding $2.5 \mathrm{mM}$ sodium ATP after $4 \mathrm{~min}$ of initial incubation to $100 \mathrm{mM}$ MES- $100 \mathrm{mM}$ Tris buffer ( $\mathrm{pH}$ 6.0) containing $5 \mathrm{mM} \mathrm{MgCl}_{2}$ and $200 \mathrm{mM} \mathrm{KCl}$. The reaction was stopped after 2,4 , and $6 \mathrm{~min}$ by placing the serum vial on ice. The concentration of the inorganic phosphate produced was measured spectrophotometrically as described previously (Heinonen and Lahti, 1981).

The following anaerobic enzyme activity assays were measured spectrophotometrically using the soluble protein fraction and were contained in rubber stopper-sealed glass cuvettes that had been degassed and flushed with $\mathrm{N}_{2}$. Cytoplasmic hydrogenase (Sulf) (Bryant and Adams, 1989; Ma et al., 2000) activity was determined by measuring the reduction of $1 \mathrm{mM} \mathrm{BV}$ at $600 \mathrm{~nm}\left[\varepsilon=7400\left(\mathrm{M}^{\bullet} \mathrm{cm}\right)^{-1}\right]$ under an $\mathrm{H}_{2}: \mathrm{CO}_{2}$ (80:20\%) headspace. Pyruvate:Fd oxidoreductase (POR) (Blamey and Adams, 1993) and 2-ketoisovalerate:Fd oxidoreductase (VOR) (Heider et al., 1996) activities were determined by measuring the reduction of $1 \mathrm{mM} \mathrm{MV}$ at $600 \mathrm{~nm}$ [ $\left.\varepsilon=12,000\left(\mathrm{M}^{\bullet} \mathrm{cm}\right)^{-1}\right]$ and $1 \mathrm{mM} \mathrm{BV}$, respectively, in an assay mixture that contained $2 \mathrm{mM} \mathrm{MgCl}, 0.4 \mathrm{mM}$ thiamine pyrophosphate (TPP), and $0.2 \mathrm{mM}$ coenzyme A (CoA). Pyruvate $(10 \mathrm{mM})$ and $5 \mathrm{mM}$ 2-ketoisovalerate were used as the substrates, respectively. Aldehyde:Fd oxidoreductase (AOR) (Mukund and Adams, 1991) and formaldehyde:Fd oxidoreductase (FOR) (Roy et al., 1999) activities were determined by measuring the reduction of $3 \mathrm{mM} \mathrm{BV}$ using $0.5 \mathrm{mM}$ crotonaldehyde and $0.25 \mathrm{mM}$ formaldehyde, respectively, as the substrate. Fd:NAD(P)H oxidoreductase (FNOR) (Ma and Adams, 1994) activity was determined by measuring the reduction of $3 \mathrm{mM}$ $\mathrm{BV}$ in $50 \mathrm{mM}$ CAPS buffer ( $\mathrm{pH} 10.3$ ) using $0.4 \mathrm{mM} \mathrm{NADPH}$ as the substrate. Alcohol dehydrogenase $(\mathrm{ADH})(\mathrm{Ma}$ and Adams, 1999) was determined by measuring the reduction of $0.4 \mathrm{mM}$ $\mathrm{NADP}^{+}$at $340 \mathrm{~nm}\left[\varepsilon=6220\left(\mathrm{M}^{\bullet} \mathrm{cm}\right)^{-1}\right]$ using $150 \mathrm{mM}$ ethanol as the substrate. Formate dehydrogenase (FDH) (Ma et al., 1995) activity was determined by measuring the reduction of $5 \mathrm{mM}$ $\mathrm{BV}$ at $600 \mathrm{~nm}$ in $100 \mathrm{mM}$ EPPS ( $\mathrm{pH} 8.4$ ) using $10 \mathrm{mM}$ sodium formate as the substrate. Alanine aminotransferase (AlaAT) (Ward et al., 2000) activity was determined by measuring the pyruvate evolution rate in a discontinuous assay by adding sample after $4 \mathrm{~min}$ of initial incubation to $100 \mathrm{mM} \mathrm{KCl}, 20 \mathrm{mM}$ 2-ketoglutarate, $50 \mu \mathrm{M}$ pyrodixal-5'-phosphate, and $50 \mathrm{mM}$ L-alanine. The reaction was stopped after 2,4 , and $6 \mathrm{~min}$ by placing the serum vial on ice. The amount of pyruvate in each vial was determined aerobically at room temperature using a lactate dehydrogenase assay that contained $100 \mathrm{mM}$ potassium phosphate ( $\mathrm{pH} 7.0), 0.4 \mathrm{mM} \mathrm{NADPH}$, and $50 \mathrm{U}$ of $\mathrm{LDH}$ from rabbit muscle (Sigma-Aldrich).

The following aerobic enzyme activity assays were performed using the soluble protein fraction and were measured spectrophotometrically in glass cuvettes. Glutamate dehydrogenase (GDH) (Robb et al., 1992) activity was determined by measuring the reduction of $0.4 \mathrm{mM} \mathrm{NADP}^{+}$ at $340 \mathrm{~nm}\left[\varepsilon=6220\left(\mathrm{M}^{\circ} \mathrm{cm}\right)^{-1}\right]$ using $6 \mathrm{mM}$ sodium glutamate as the substrate. ADP-forming acetyl-CoA synthetase (ACS) (Bräsen and Schönheit, 2004) activity was determined by measuring the production of DTNB-CoA by adding sample to $100 \mathrm{mM}$ MOPS buffer (pH 7.0), 0.25 mM DTNB, $5 \mathrm{mM} \mathrm{MgCl}_{2}$, $1 \mathrm{mM}$ ADP, $5 \mathrm{mM} \mathrm{K}_{2} \mathrm{HPO}_{4}$, and $0.2 \mathrm{mM}$ acetyl-CoA.

\section{Statistical Analyses}

Results were subjected to statistical analyses in R (R Core Team, 2013). The growth rates, metabolite production rates, enzyme activities, and colony-forming-unit yields were compared using analysis of variance (ANOVA) and Tukey's Honestly Significant Difference test $(\alpha=0.05)$. The mean of at least three replicates are reported as means \pm standard error (SE).

\section{RESULTS}

\section{Growth and Metabolite Production}

Both T. paralvinellae and P. furiosus grew and produced $\mathrm{H}_{2}$ in the various maltose- and tryptone-containing media over $12-$ $24 \mathrm{~h}$ (Figure 2), the milk waste media over $100 \mathrm{~h}$ (Figure 3) and the spent brewery grain media over $100 \mathrm{~h}$ (Figure 4). Neither organism grew on the $0.5 \%$ lactose plus $0.01 \%$ yeast extract medium. For both organisms, the maltose-tryptone medium was among those that produced the largest cell $\max$ and $r_{\max }$ (Table 1). For T. paralvinellae, this condition was among those that also showed the largest $q$ (specific $\mathrm{H}_{2}$ production rate) $\left(\mathrm{F}_{4}=330.6\right.$, $p<0.001)$. While $\mathrm{H}_{2}$ was the primary metabolite produced, both organisms also produced acetate, butyrate, succinate, isovalerate, and formate (Table 2). Relative to $\mathrm{H}_{2}$ production, acetate production was highest in tryptone-only and maltose-acetate media for T. paralvinellae and in maltose-only medium for $P$. furiosus. Assuming four acetate molecules produced per molecule of maltose consumed, less than $0.5 \mathrm{mM}$ maltose was used by either organism. Succinate, isovalerate and butyrate were also produced in various media (Table 2). T. paralvinellae produced formate when grown on maltose-only medium, while $P$. furiosus produced it in maltose-only and maltose-acetate media (Table 2). Ethanol was not detected in any medium tested for either organism.

\section{Growth and $\mathrm{H}_{2}$ Production in Waste Media}

T. paralvinellae produced increasingly higher amounts of $\mathrm{H}_{2}$ with increasing concentration of waste milk for both milk types (Figure 3). The increase in $\mathrm{H}_{2}$ production continued with increasing milk concentration up to the highest concentration tested (70\%; data not shown). For P. furiosus, the amount of $\mathrm{H}_{2}$ produced from $1 \%$ waste milk was higher than the amount 

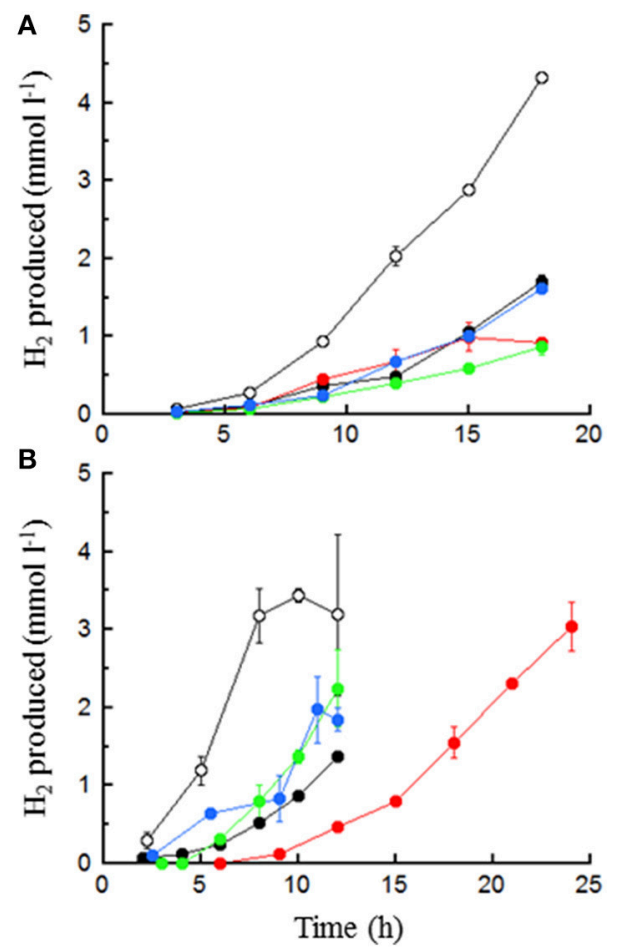

FIGURE 2 | $\mathrm{H}_{2}$ production by $T$. paralvinellae $(A)$ and $P$. furiosus (B) in $0.5 \%$ maltose (O), $0.5 \%$ tryptone $(0), 0.5 \%$ maltose $+0.05 \%$ tryptone (๑), $0.5 \%$ maltose $+10 \mathrm{mM}$ acetate $(\bullet)$, and $0.5 \%$ maltose at pH 5.0 (๑). Error bars represent the standard error.

for both 0.1 and $10 \%$ waste milk (Figure 3). T. paralvinellae produced more $\mathrm{H}_{2}$ than $P$. furiosus in all waste conditions tested except $0.1 \%$ milk from Ceftiofur-treated cows and $1 \%$ milk from untreated cows. Growth and $\mathrm{H}_{2}$ production did not significantly change for either microorganism between waste milk from cows treated with Ceftiofur and from untreated cows. There was visual clarification by eye of waste milk media following $100 \mathrm{~h}$ of incubation at $82^{\circ} \mathrm{C}$ with $T$. paralvinellae, but not in the uninoculated control bottle incubated at the same temperature (Figure 5A). When 1\% waste milk was incubated with $T$. paralvinellae, the concentration of soluble protein decreased to undetectable concentrations within $48 \mathrm{~h}$ and was significantly lower $(p<0.01)$ than the soluble protein concentrations in uninoculated bottles (Figure 5B). The amount of reducing sugars in the milk (Figure 5C) and the total COD decreased over time, but the concentrations were not significantly different from those in uninoculated bottles. Cell counts were highly variable when grown on milk due to precipitation and clumping of the milk at high temperatures.

T. paralvinellae produced increasing amounts of $\mathrm{H}_{2}$ (up to $6 \mathrm{mmol} \mathrm{l}^{-1}$ ) with increasing amounts of spent brewery grain as the feedstock (Figure 4). In contrast, P. furiosus produced less than $1 \mathrm{mmol}$ of $\mathrm{H}_{2} \mathrm{l}^{-1}$ on $0.1,1$, and $10 \%$ spent brewery grain (Figure 4). Microscopically, neither T. paralvinellae nor $P$. furiosus were preferentially associated with the cellulose fibers of the spent brewery grain, but could not be accurately counted due to the presence of the grain.
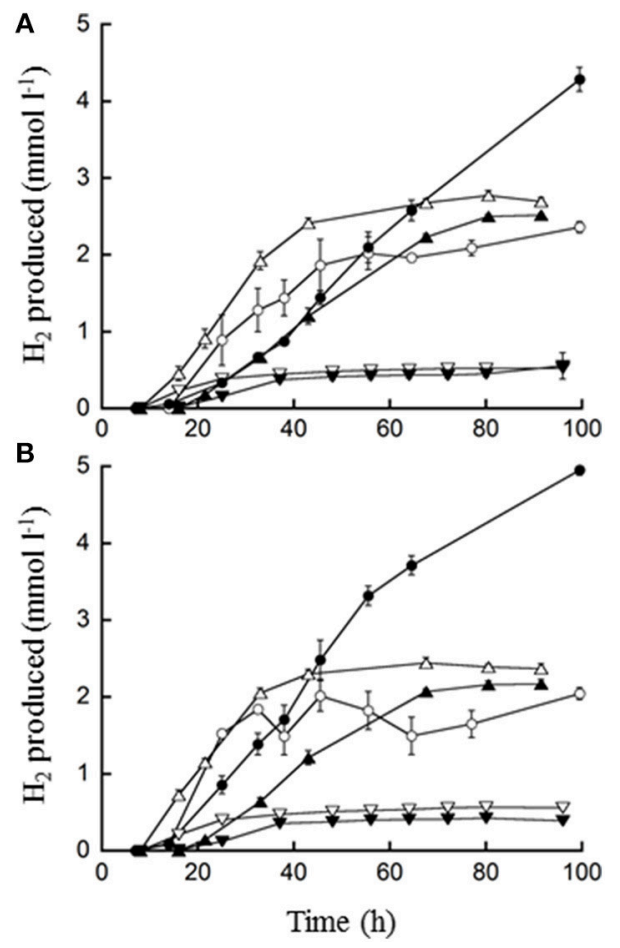

FIGURE 3 | $\mathrm{H}_{2}$ production by $T$. paralvinellae (filled symbols) and $P$. furiosus (open symbols) when grown on waste milk from cows treated with Ceftiofur (A) and from untreated cows (B). The concentrations of waste milk used were $10(\mathrm{O}, \bullet), 1(\Delta, \mathbf{\Delta})$, and $0.1 \%(\nabla, \boldsymbol{\nabla})$. Error bars represent the standard error.

\section{Remediation of Waste Milk}

Dilution-to-extinction plating of $1 \%$ milk showed that milk from Ceftiofur-treated cows and untreated cows contain similar concentrations of bacteria prior to incubation (Table 3). The exception was that there were colony-forming units found on MacConkey agar plates, which is selective for Gram-negative enteric bacteria, from untreated cows that were completely absent from plates from cows treated with Ceftiofur. Also, the concentrations of $\lambda$ colonies on Sheep's Blood agar plates, which can represent Staphylococcus spp. (the typical cause of mastitis), were higher in cows being treated for mastitis. All plate types showed no colony forming units from medium that had been incubated with $T$. paralvinellae for $100 \mathrm{~h}$ at $82^{\circ} \mathrm{C}$ (Table 3). The concentration of Ceftiofur in waste milk from a cow treated within $48 \mathrm{~h}$ of milking was $25.7 \pm 0.2 \mathrm{ng} \mathrm{m}^{-1}$ (mean \pm standard error). With and without inoculation with $T$. paralvinellae, the amount of Ceftiofur in $10 \%$ waste milk medium was below the detection limit within an hour of incubation at $82^{\circ} \mathrm{C}$.

\section{Growth in a 20-I Bioreactor}

The growth rates of $T$. paralvinellae in the bioreactor were $0.67 \pm$ $0.06 \mathrm{~h}^{-1}$ (mean \pm standard error) on maltose only ( $\mathrm{pH} \mathrm{6.8),}$ $0.59 \pm 0.05 \mathrm{~h}^{-1}$ on tryptone only, $0.53 \pm 0.14 \mathrm{~h}^{-1}$ on maltose plus tryptone, $0.38 \pm 0.05 \mathrm{~h}^{-1}$ on maltose plus acetate, $0.36 \pm$ $0.04 \mathrm{~h}^{-1}$ on maltose only ( $\mathrm{pH} 5.0$ ), and $0.49 \pm 0.09 \mathrm{~h}^{-1}$ on milk containing Ceftiofur (Figure 6A). For T. paralvinellae, specific 
TABLE 1 | T. paralvinellae and $P$. furiosus kinetic parameters.

\begin{tabular}{|c|c|c|c|c|c|c|}
\hline \multirow[t]{2}{*}{ Kinetic parameter ${ }^{\dagger}$} & \multicolumn{5}{|c|}{ Media type } & \multirow[t]{2}{*}{$p$-value } \\
\hline & $0.5 \%$ maltose & $0.5 \%$ tryptone & $0.5 \%$ maltose $+0.05 \%$ tryptone & $0.5 \%$ maltose $+10 \mathrm{mM}$ acetate & $0.5 \%$ maltose $(\mathrm{pH} 5)$ & \\
\hline \multicolumn{7}{|l|}{ T. paralvinellae } \\
\hline$\mu\left(h^{-1}\right)$ & $0.45 \pm 0.11$ & $0.35 \pm 0.21$ & $0.34 \pm 0.13$ & $0.32 \pm 0.08$ & $0.35 \pm 0.11$ & NS \\
\hline cell $\max \left(\times 10^{7}, \mathrm{ml}^{-1}\right)$ & $13^{a}$ & $6^{b}$ & $13^{a}$ & $8^{b}$ & $5^{b}$ & * \\
\hline$Y_{\mathrm{p} / \mathrm{x}}\left(\mathrm{fmol} \mathrm{H}_{2} \mathrm{cell}^{-1}\right)$ & $13 \pm 3^{a}$ & $16 \pm 5^{a}$ & $32 \pm 7^{b}$ & $10 \pm 1^{a}$ & $32 \pm 8^{b}$ & $\star \star \star ~$ \\
\hline$q\left(\mathrm{fmol} \mathrm{H}_{2}\right.$ cell $\left.^{-1} \mathrm{~h}^{-1}\right)$ & $8 \pm 3^{a}$ & $8 \pm 3^{a}$ & $16 \pm 5^{b}$ & $5 \pm 1^{a}$ & $16 \pm 4^{b}$ & *** \\
\hline$r_{\max }\left(\mathrm{mmol} \mathrm{H} \mathrm{H}^{-1} \mathrm{~h}^{-1}\right)$ & $1.1 \pm 0.5^{a, b}$ & $0.5 \pm 0.3^{a}$ & $2.0 \pm 0.8^{b}$ & $0.4 \pm 0.1^{a}$ & $0.8 \pm 0.4^{a}$ & $\star \star$ \\
\hline \multicolumn{7}{|l|}{ P. furiosus } \\
\hline$\mu\left(\mathrm{h}^{-1}\right)$ & $0.43 \pm 0.08$ & $0.31 \pm 0.22$ & $0.49 \pm 0.25$ & $0.54 \pm 0.13$ & $0.39 \pm 0.10$ & NS \\
\hline cellmax $\left(\times 10^{7}, \mathrm{ml}^{-1}\right)$ & $10^{a, b}$ & $6^{b}$ & $19^{a}$ & $4^{b}$ & $8^{b}$ & $\star \star$ \\
\hline$Y_{\mathrm{p} / \mathrm{x}}\left(\mathrm{fmol} \mathrm{H}_{2}\right.$ cell $\left.^{-1}\right)$ & $11 \pm 2^{a}$ & $42 \pm 11^{a, b}$ & $17 \pm 3^{a, b}$ & $46 \pm 29^{b}$ & $17 \pm 8^{a, b}$ & ** \\
\hline$q\left(\mathrm{fmol} \mathrm{H} \mathrm{cell}^{-1} \mathrm{~h}^{-1}\right)$ & $7 \pm 1^{a}$ & $19 \pm 6^{a, b}$ & $12 \pm 4^{a, b}$ & $36 \pm 24^{b}$ & $10 \pm 5^{a, b}$ & ** \\
\hline$r_{\max }\left(\mathrm{mmol} \mathrm{H} \mathrm{I}^{-1} \mathrm{~h}^{-1}\right)$ & $0.7 \pm 0.2^{a}$ & $1.1 \pm 0.3^{a}$ & $2.3 \pm 0.8^{b}$ & $1.4 \pm 0.8^{a, b}$ & $0.7 \pm 0.3^{a}$ & * \\
\hline
\end{tabular}

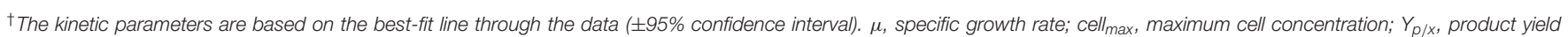

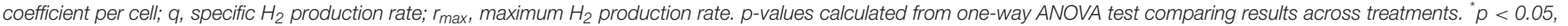
${ }^{* *} p<0.01$, and ${ }^{* * *} p<0.001$. ${ }^{a, b}$ Tukey post-hoc test indicates groups whose members are not significantly different. NS, no significance.

TABLE 2 | Mean product formation ( $\mathrm{mM}, \pm$ standard error) by $T$. paralvinellae and $P$. furiosus after $18 \mathrm{~h}$ of incubation in the defined media relative to uninoculated controls.

\begin{tabular}{|c|c|c|c|c|c|}
\hline Product & $0.5 \%$ maltose & $0.5 \%$ tryptone & $0.5 \%$ maltose $+0.05 \%$ tryptone & $0.5 \%$ maltose $+10 \mathrm{mM}$ acetate & $0.5 \%$ maltose $(\mathrm{pH} 5)$ \\
\hline \multicolumn{6}{|c|}{ T. paralvinellae } \\
\hline $\mathrm{H}_{2}$ & $0.47 \pm 0.04$ & $0.76 \pm 0.02$ & $1.18 \pm 0.00$ & $0.29 \pm 0.01$ & $0.05 \pm 0.01$ \\
\hline Acetate & $0.20 \pm 0.01$ & $1.14 \pm 0.09$ & $0.30 \pm 0.03$ & $0.69 \pm 0.00$ & $0.01 \pm 0.00$ \\
\hline Butyrate & 0 & 0 & 0 & $0.06 \pm 0.00$ & 0 \\
\hline Succinate & 0 & $0.24 \pm 0.01$ & 0 & 0 & 0 \\
\hline Isovalerate & 0 & $0.31 \pm 0.00$ & $0.02 \pm 0.01$ & 0 & 0 \\
\hline Formate & 0 & $0.54 \pm 0.06$ & 0 & 0 & 0 \\
\hline \multicolumn{6}{|l|}{$P$ furiosus } \\
\hline $\mathrm{H}_{2}$ & $2.00 \pm 0.00$ & $1.71 \pm 0.08$ & $4.92 \pm 0.47$ & $5.51 \pm 1.18$ & $3.71 \pm 0.16$ \\
\hline Acetate & $0.95 \pm 0.05$ & $0.06 \pm 0.05$ & $1.14 \pm 0.27$ & $1.66 \pm 0.28$ & $0.79 \pm 0.06$ \\
\hline Butyrate & 0 & 0 & $0.01 \pm 0.00$ & 0 & 0 \\
\hline Succinate & $0.14 \pm 0.01$ & $0.10 \pm 0.00$ & 0 & $0.22 \pm 0.16$ & 0 \\
\hline Isovalerate & 0 & $0.46 \pm 0.00$ & $0.28 \pm 0.28$ & 0 & 0 \\
\hline Formate & $2.14 \pm 0.08$ & 0 & $0.01 \pm 0.01$ & $1.51 \pm 0.25$ & 0 \\
\hline
\end{tabular}

growth rates increased in the bioreactor relative to bottles when the cultures were grown on maltose and maltose-tryptone media. Otherwise, specific growth rates on the other three defined media were unchanged. T. paralvinellae growth rates on maltose at $\mathrm{pH}$ 5 or in the presence of acetate were lower in the bioreactor than maltose only in the bioreactor suggesting that $\mathrm{pH}$ and acetate can have some inhibitory effect in a bioreactor. Specific growth rates of $P$. furiosus on each of the media increased significantly in the 20-1 bioreactor relative to growth in serum bottles (Figure 6B). The growth rates of $P$. furiosus in the bioreactor were $0.95 \pm 0.08$ $\mathrm{h}^{-1}$ (mean \pm standard error) on maltose only ( $\mathrm{pH} 6.8$ ), $0.73 \pm$ $0.04 \mathrm{~h}^{-1}$ on tryptone only, $0.73 \pm 0.05 \mathrm{~h}^{-1}$ on maltose plus tryptone, $0.67 \pm 0.06 \mathrm{~h}^{-1}$ on maltose plus acetate, $0.71 \pm 0.02$ $\mathrm{h}^{-1}$ on maltose only (pH 5.0), and $0.29 \pm 0.03 \mathrm{~h}^{-1}$ on milk with Ceftiofur. As seen in the bottles, the maximum cell concentration of $P$. furiosus in the bioreactor on peptide medium was much lower than rates on maltose and maltose-tryptone media, while there was no difference in the growth rates in these media with $T$. paralvinellae.

\section{Enzyme Activities}

A summary of all specific enzyme activities are provided in Table 4. Overall, enzymatic activities in both organisms changed the most when cells were grown under stressful conditions. $T$. paralvinellae and $P$. furiosus showed the largest dissimilarity in enzyme activities when grown on maltose-acetate medium (11 of 13 enzymes for both organisms) and low $\mathrm{pH}$ maltose medium (6 of 13 activities for T. paralvinellae and 2 of 13 enzymes for $P$. furiosus). For T. paralvinellae, membrane-bound ATP synthase, $\mathrm{GDH}$, and AlaAT activities were higher than all other enzyme 
activities. For P. furiosus, Mbh activities were higher than any other enzyme activity for all defined media except for FNOR activity which was higher when cells were grown on maltoseonly medium and GDH activity which was higher when cells were grown on tryptone-only medium.

Mbh and ATP synthase activities could not be measured from cells grown on milk due to co-precipitation of insoluble cell fractions with heat curdled milk. The Mbh activities in $T$. paralvinellae did not show any significant change between the defined media. In contrast, Mbh activity in $P$. furiosus cells grown in maltose-tryptone medium was higher $\left(\mathrm{F}_{4}=12.05, p<0.05\right)$ than activities in cells from maltose and low $\mathrm{pH}$ maltose media, and activity in cells from maltose-acetate medium was higher than that in cells from maltose medium. Mbh activities in $P$. furiosus were higher than those in T. paralvinellae for cells grown on maltose-tryptone $\left(\mathrm{F}_{1}=798, p<0.001\right)$, maltose-acetate $\left(\mathrm{F}_{1}=847, p<0.005\right)$, and low $\mathrm{pH}$ maltose $\left(\mathrm{F}_{1}=142.9\right.$, $p<0.01)$ media. Sulf activities from maltose-tryptone medium were higher in $T$. paralvinellae and $P$. furiosus cells than activities in cells from the other four defined media and $1 \%$ milk medium $\left(\mathrm{F}_{5}=23.2, p<0.001\right)$. Sulf activities were higher in $P$. furiosus than in $T$. paralvinellae for cells grown on maltose $\left(\mathrm{F}_{1}=66.7\right.$,

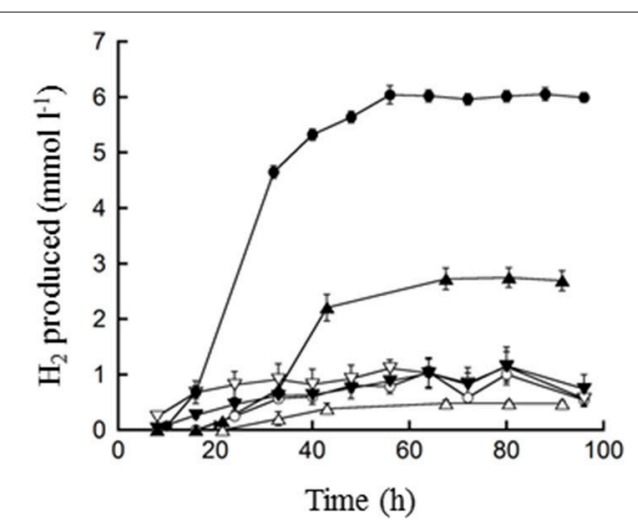

FIGURE $4 \mid \mathrm{H}_{2}$ production by $T$. paralvinellae (filled symbols) and $P$. furiosus (open symbols) when grown on spent brewery grain. The concentrations spent grain used were $10(\mathrm{O}, \bullet), 1(\Delta, \mathbf{\Lambda})$, and $0.1 \%(\nabla, \mathbf{\nabla})$. Error bars represent the standard error. $p<0.001)$, maltose-tryptone $\left(\mathrm{F}_{1}=14.5, p<0.01\right)$, and maltose-acetate $\left(\mathrm{F}_{1}=20.5, p<0.01\right)$ media. Membrane-bound ATP synthase activity in T. paralvinellae was higher in cells grown on maltose-acetate and tryptone media than on the other three defined media $\left(\mathrm{F}_{4}=54.2, p<0.001\right)$. In P. furiosus, ATP synthase activity in cells grown on maltose-tryptone medium was higher than activities in cells from the other four defined media $\left(\mathrm{F}_{4}=10.4, p<0.02\right)$. Membrane-bound ATP synthase activity was higher in $T$. paralvinellae than in $P$. furiosus for cells grown on tryptone $\left(\mathrm{F}_{1}=57.0, p<0.02\right)$, maltose-acetate $\left(\mathrm{F}_{1}=\right.$ $\left.2.1 \times 10^{4}, p<0.001\right)$, and low $\mathrm{pH}$ maltose $\left(\mathrm{F}_{1}=44.4, p<0.05\right)$ media.

In T. paralvinellae, AOR and FNOR activities were higher in cells grown on maltose-acetate medium than any of the other four defined media and $1 \%$ waste milk medium $\left(\mathrm{F}_{5}=7.75\right.$, $p<0.001$ and $\mathrm{F}_{5}=37.72, p<0.001$, respectively). FNOR activity was lower in cells grown on maltose medium than on maltose-tryptone and tryptone media $\left(\mathrm{F}_{5}=37.73, p<0.01\right)$. VOR activity was higher in cells grown on maltose and maltosetryptone media than any other media $\left(\mathrm{F}_{5}=14.45, p<0.05\right)$, POR activity was higher in cells grown on maltose and low $\mathrm{pH}$ maltose media than any other media $\left(\mathrm{F}_{5}=30.32, p<0.05\right)$, and GDH activity was higher $\left(\mathrm{F}_{5}=28.8, p<0.02\right)$ in cells grown on maltose medium than cells grown on low $\mathrm{pH}$ maltose, maltoseacetate, maltose-tryptone, and $1 \%$ milk media. In P. furiosus, GDH activity was higher in cells grown on tryptone medium than any of the other four defined media and $1 \%$ waste milk $\left(\mathrm{F}_{5}=\right.$ 50.0, $p<0.001)$. POR activity was higher in cells grown on maltose medium than any of the other four defined media and $1 \%$ waste milk $\left(\mathrm{F}_{5}=11.28, p<0.001\right)$. The other enzyme activities for both organisms either did not change with growth medium or did not show a consistent pattern in their differences.

\section{DISCUSSION}

\section{Growth, $\mathrm{H}_{2}$ Production Kinetics, and Enzyme Activities}

T. paralvinellae ES1 was isolated from a polychaete worm collected from a deep-sea hydrothermal vent in the northeastern Pacific Ocean and is commonly associated with growth on peptides and sulfur to produce $\mathrm{H}_{2} \mathrm{~S}$ (Pledger and Baross, 1989).

TABLE 3 | Mean colony forming units ( $($ standard error, $n=3)$ per $\mathrm{ml}$ of fresh $(<2 \mathrm{~h}$ old $) 1 \%\left(\mathrm{vol} \mathrm{vol}^{-1}\right)$ waste milk from Ceftiofur-treated and untreated cows in base medium, and base medium without a carbon source.

\begin{tabular}{|c|c|c|c|c|c|c|}
\hline \multirow[t]{2}{*}{ Treatment } & \multirow[t]{2}{*}{ Luria Broth $\left(\times 10^{3}\right)$} & \multicolumn{3}{|c|}{ Sheep's blood } & \multicolumn{2}{|c|}{ MacConkey } \\
\hline & & $\alpha\left(\times 10^{2}\right)$ & $\beta\left(\times 10^{2}\right)$ & $\lambda\left(\times 10^{2}\right)$ & Fermenter & Non-fermenter \\
\hline \multicolumn{7}{|c|}{ WITHOUT HEAT TREATMENT } \\
\hline Ceftiofur-treated & $5.7 \pm 4.2$ & $7.0 \pm 3.0$ & $2.0 \pm 0.3$ & $93 \pm 77$ & 0 & 0 \\
\hline Untreated & $4.4 \pm 3.7$ & $4.3 \pm 3.8$ & $4.6 \pm 2.8$ & $2.6 \pm 1.2$ & $3 \pm 3$ & $66 \pm 56$ \\
\hline Control & 0 & 0 & 0 & 0 & 0 & 0 \\
\hline \multicolumn{7}{|l|}{$100 \mathrm{~h}$ at $82^{\circ} \mathrm{C}$} \\
\hline Ceftiofur-treated & 0 & 0 & 0 & 0 & 0 & 0 \\
\hline Untreated & 0 & 0 & 0 & 0 & 0 & 0 \\
\hline Control & 0 & 0 & 0 & 0 & 0 & 0 \\
\hline
\end{tabular}


TABLE 4 | T. paralvinellae and $P$. furiosus specific enzyme activities.

\begin{tabular}{|c|c|c|c|c|c|c|c|}
\hline \multirow[t]{2}{*}{ Enzyme $^{\dagger}$} & \multicolumn{6}{|c|}{ Media type } & \multirow[t]{2}{*}{$p$-value } \\
\hline & $0.5 \%$ maltose & $0.5 \%$ tryptone & $\begin{array}{l}0.5 \% \text { maltose } \\
0.05 \% \text { tryptone }\end{array}$ & $\begin{array}{c}0.5 \% \text { maltose }+ \\
10 \mathrm{mM} \text { acetate }\end{array}$ & $0.5 \%$ maltose $(\mathrm{pH} 5)$ & $1 \%$ waste milk & \\
\hline \multicolumn{8}{|c|}{ T. paralvinellae } \\
\hline Mbh & $3.34 \pm 0.91$ & $4.62 \pm 2.20$ & $1.53 \pm 0.31$ & $1.36 \pm 0.29$ & $0.18 \pm 0.18$ & ND & NS \\
\hline Sulf & $0.21 \pm 0.03^{a}$ & $0.54 \pm 0.20^{a}$ & $1.53 \pm 0.15$ & $0.06 \pm 0.01^{a}$ & $0.05 \pm 0.01^{a}$ & $0.35 \pm 0.14^{a}$ & 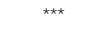 \\
\hline ATPase & $0.23 \pm 0.04^{a, b}$ & $3.30 \pm 0.44^{d}$ & $0.39 \pm 0.29^{a, c}$ & $4.41 \pm 0.03^{d}$ & $1.33 \pm 0.20^{b, c}$ & ND & $\star \star \star ~$ \\
\hline FNOR & $0.21 \pm 0.07^{a}$ & $3.42 \pm 0.16^{c, d}$ & $3.33 \pm 0.60^{b, c}$ & $9.10 \pm 1.02$ & $1.84 \pm 0.22^{a, b, d}$ & $1.71 \pm 0.22^{a, b, d}$ & 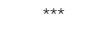 \\
\hline $\mathrm{GDH}$ & $12.09 \pm 0.75^{a}$ & $9.03 \pm 0.56^{a, c}$ & $3.88 \pm 1.26^{b}$ & $3.89 \pm 0.91^{b}$ & $8.31 \pm 0.30^{c}$ & $0.53 \pm 0.14^{b}$ & 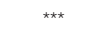 \\
\hline AlaAT & $1.21 \pm 0.47^{a}$ & $5.80 \pm 2.46^{a, b}$ & $5.08 \pm 1.27^{a, b}$ & $3.01 \pm 0.11^{a, b}$ & $8.00 \pm 0.37^{b}$ & $2.42 \pm 0.45^{a, b}$ & * \\
\hline POR & $2.59 \pm 0.13^{a}$ & $0.46 \pm 0.10^{b}$ & $1.29 \pm 0.09$ & $0.41 \pm 0.05^{b}$ & $2.16 \pm 0.40^{a}$ & $0.18 \pm 0.05^{b}$ & $* \star \star$ \\
\hline VOR & $0.34 \pm 0.07^{a}$ & $0.11 \pm 0.03^{b}$ & $0.44 \pm 0.05^{a}$ & $0.02 \pm 0.01^{b}$ & $0.11 \pm 0.03^{b}$ & $0.14 \pm 0.03^{b}$ & $\star \star \star ~$ \\
\hline ACS & $0.34 \pm 0.07^{a}$ & $0.52 \pm 0.02^{b}$ & $0.60 \pm 0.03^{b}$ & $0.21 \pm 0.02^{a, c}$ & $0.60 \pm 0.02^{b}$ & $0.13 \pm 0.06^{c}$ & 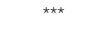 \\
\hline AOR & $0.35 \pm 0.05^{a}$ & $0.48 \pm 0.09^{a}$ & $0.29 \pm 0.05^{a}$ & $0.60 \pm 0.10^{a}$ & $1.55 \pm 0.43$ & $0.10 \pm 0.03^{a}$ & 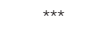 \\
\hline FOR & $0.28 \pm 0.10^{a, b}$ & $0.62 \pm 0.14^{b}$ & $0.12 \pm 0.03^{a}$ & $0.34 \pm 0.13^{a, b}$ & $0.46 \pm 0.06^{a, b}$ & $0.16 \pm 0.02^{a}$ & ** \\
\hline $\mathrm{ADH}$ & $0.03 \pm 0.01^{a, b}$ & $0.02 \pm 0.00^{a, b}$ & $0.07 \pm 0.03^{a}$ & $0^{b}$ & $0.02 \pm 0.01^{a, b}$ & $0^{b}$ & $\star \star$ \\
\hline $\mathrm{FDH}$ & $0.06 \pm 0.02^{a}$ & $0.03 \pm 0.00^{a, b}$ & $0.02 \pm 0.00^{a, b}$ & $0.04 \pm 0.01^{a, b}$ & $0.02 \pm 0.00^{a, b}$ & $0.01 \pm 0.01^{b}$ & * \\
\hline \multicolumn{8}{|c|}{ P. furiosus } \\
\hline Mbh & $4.99 \pm 0.31^{a}$ & $9.55 \pm 0.50^{a, b}$ & $12.74 \pm 0.24^{b}$ & $11.42 \pm 0.19^{b}$ & $5.39 \pm 0.40^{a, b}$ & ND & ** \\
\hline Sulf & $1.27 \pm 0.11^{a, b, c}$ & $0.73 \pm 0.19^{a, c, d}$ & $3.44 \pm 0.49$ & $1.48 \pm 0.29^{a, b, e}$ & $0.15 \pm 0.05^{d, f}$ & $0.52 \pm 0.02^{c, e, f}$ & 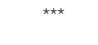 \\
\hline ATPase & $0.05 \pm 0.00^{a}$ & $0.01 \pm 0.01^{a}$ & $0.70 \pm 0.22$ & $0^{a}$ & $0^{a}$ & ND & * \\
\hline FNOR & $6.10 \pm 0.60^{a}$ & $3.90 \pm 0.32^{a, b}$ & $4.59 \pm 0.48^{a}$ & $3.83 \pm 0.47^{a, b}$ & $0.31 \pm 0.12^{b}$ & $3.16 \pm 1.59^{a, b}$ & $\star \star \star \star$ \\
\hline $\mathrm{GDH}$ & $1.85 \pm 0.36^{a}$ & $9.90 \pm 1.08^{C}$ & $4.69 \pm 0.42^{b}$ & $0.69 \pm 0.08^{a}$ & $0.91 \pm 0.09^{a}$ & $0.68 \pm 0.16^{a}$ & 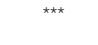 \\
\hline AlaAT & $0.54 \pm 0.25$ & $3.05 \pm 0.61$ & $2.59 \pm 1.76$ & $0.72 \pm 0.14$ & $0.36 \pm 0.05$ & $0.54 \pm 0.29$ & NS \\
\hline POR & $2.27 \pm 0.43$ & $0.93 \pm 0.10^{a}$ & $0.72 \pm 0.03^{a}$ & $0.85 \pm 0.09^{a}$ & $0.30 \pm 0.02^{a}$ & $0.01 \pm 0.01^{a}$ & 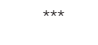 \\
\hline VOR & $1.88 \pm 0.23^{a}$ & $2.01 \pm 0.45^{a}$ & $0.56 \pm 0.12^{b, c}$ & $0.56 \pm 0.06^{b, d}$ & $1.35 \pm 0.05^{a, b, d}$ & $0.11 \pm 0.05^{c, d}$ & $\star \star \star \star ~$ \\
\hline ACS & $0.87 \pm 0.09^{a, b, c}$ & $1.30 \pm 0.12^{b}$ & $1.15 \pm 0.24^{a}$ & $0.68 \pm 0.09^{a, c}$ & $0.57 \pm 0.04^{a, c}$ & $0.44 \pm 0.19^{C}$ & 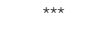 \\
\hline AOR & $0.36 \pm 0.04^{a}$ & $0.12 \pm 0.03^{b, c, d}$ & $0.24 \pm 0.01^{a, b, d}$ & $0.26 \pm 0.07^{a, c}$ & $0.08 \pm 0.02^{d}$ & $0.06 \pm 0.02^{d}$ & 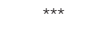 \\
\hline FOR & $0.47 \pm 0.08$ & $0.27 \pm 0.06$ & $0.36 \pm 0.01$ & $0.45 \pm 0.11$ & $0.31 \pm 0.09$ & $0.47 \pm 0.23$ & NS \\
\hline $\mathrm{ADH}$ & 0 & 0 & $0.01 \pm 0.00$ & 0 & 0 & $0.01 \pm 0.01$ & NS \\
\hline $\mathrm{FDH}$ & $0.02 \pm 0.00$ & $0.06 \pm 0.02$ & $0.02 \pm 0.01$ & $0.01 \pm 0.01$ & $0.03 \pm 0.01$ & 0 & NS \\
\hline
\end{tabular}

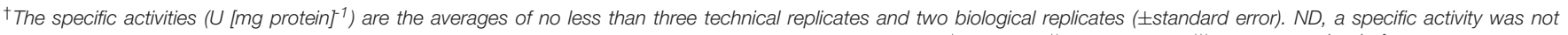

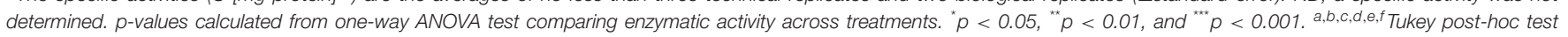
indicates groups whose members are not significantly different. NS, no significance.

However, T. paralvinellae possesses seven hydrogenase gene clusters (Jung et al., 2014) and produces $\mathrm{H}_{2}$ in lieu of $\mathrm{H}_{2} \mathrm{~S}$ when sulfur is omitted from the medium (Hensley et al., 2014). In this study, T. paralvinellae produced $\mathrm{H}_{2}$ when grown without sulfur on either a carbohydrate (maltose) or on peptides and under potentially inhibiting conditions such as high acetate concentrations and at $\mathrm{pH}$ 5. The maltose-tryptone medium improved $\mathrm{H}_{2}$ production for T. paralvinellae (Figure 2) rather than have no effect or a negative effect as observed with most mesophilic and thermophilic anaerobes (Kim et al., 2004; Pawar and van Niel, 2013). In many other $\mathrm{H}_{2}$ producing organisms, as the $\mathrm{pH}$ decreases $\mathrm{H}_{2}$ production becomes increasingly inhibited due to the effect of low $\mathrm{pH}$ on hydrogenases (Dabrock et al., 1992). While pH 5 did decrease the specific activity of many enzymes in T. paralvinellae and P. furiosus, it did not decrease the growth or $\mathrm{H}_{2}$ production rates relative to growth on maltose at $\mathrm{pH}$ 6.8. It was previously reported that the addition of 30 and $60 \mathrm{mM}$ acetate did not affect the growth of P. furiosus (Krahe et al., 1996), but this is the first study to measure the impact of acetate on $\mathrm{H}_{2}$ production kinetics and enzyme activities. $T$. paralvinellae grew and produced $\mathrm{H}_{2}$ at rates and yields that were comparable to those of $P$. furiosus without sulfur on all media types tested. These data demonstrate that T. paralvinellae is amenable to producing $\mathrm{H}_{2}$ on diverse substrates and conditions.

Although the $\mathrm{H}_{2}$ production yields $\left(Y_{p / x}\right)$ for the defined media were generally similar between $T$. paralvinellae and $P$. furiosus, the MV-dependent Mbh activity was lower in $T$. paralvinellae than in $P$. furiosus for most media. T. paralvinellae also produced larger amounts of $\mathrm{H}_{2}$ than $P$. furiosus when grown on high concentrations of wastes. These results may be due to differing $\mathrm{H}_{2}$ production pathways in the two organisms. T. paralvinellae possesses genes for putative $\mathrm{CO}-, \mathrm{F}_{420^{-}}$, and formate-dependent hydrogenases that are lacking in P. furiosus, in addition to the Mbh and Sulf in both organisms (Jung et al., 2014). If active, they may ameliorate possible $\mathrm{H}_{2}$ inhibition 
A
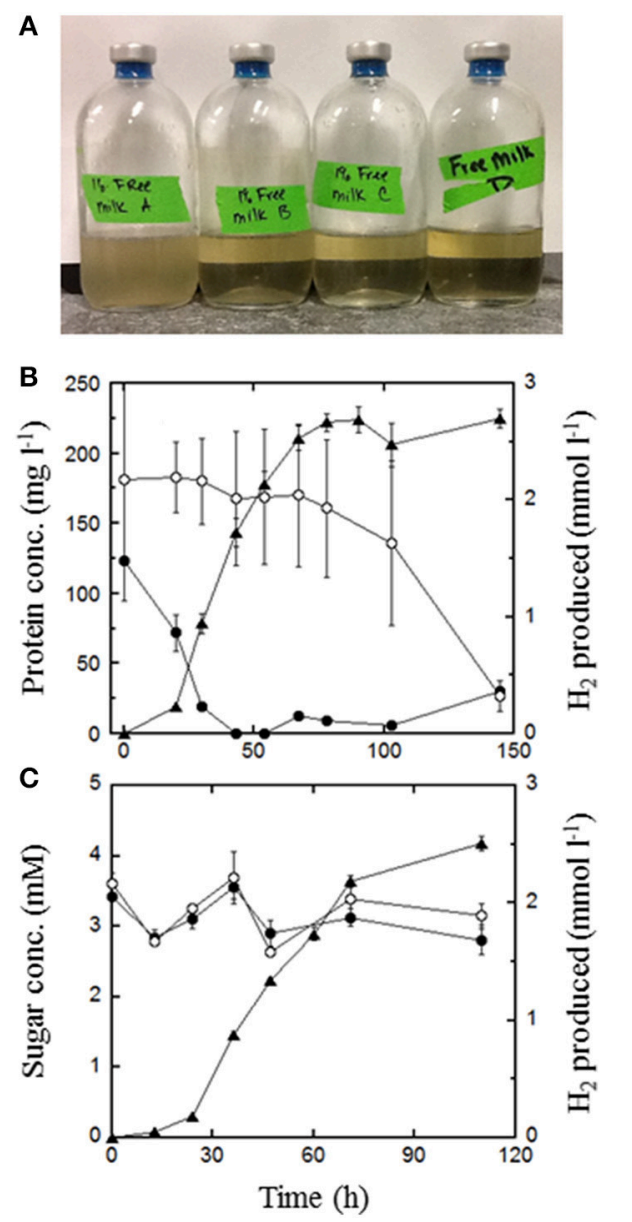

FIGURE 5 | Degradation of waste milk by T. paralvinellae during $100 \mathrm{~h}$ of incubation at $82^{\circ} \mathbf{C}$. (A) Clarification of media containing $1 \%$ waste milk from untreated cows following $100 \mathrm{~h}$ incubation. The bottle on the left was an uninoculated control. Concentrations of protein (B) and reducing sugars (C) in $1 \%$ waste milk from untreated cows. The data shown are from inoculated bottles (•) and from uninoculated controls (O) as well as $\mathrm{H}_{2}$ produced from inoculated bottles $(\boldsymbol{\Delta})$. There was no $\mathrm{H}_{2}$ production in uninoculated bottles. Error bars represent the standard error.

by having a more diverse electron carrier pool to draw from. For T. paralvinellae, POR, VOR, AOR, and GDH activities were significantly higher and FNOR lower when grown on maltose-containing media relative to the other media. Enzyme activities and metabolite production in P. furiosus were largely as previously described (Adams et al., 2001; Schut et al., 2003). POR activity in $P$. furiosus was significantly higher in cells grown on maltose and GDH activity was significantly higher in cells grown on peptides. This pattern differs somewhat from that seen in $T$. paralvinellae suggesting that redox balancing in T. paralvinellae might involve factors not found in P. furiosus.

As expected for both organisms, $\mathrm{H}_{2}$ :acetate ratios were approximately two when cultures were grown on maltose-only medium, and isovalerate was only produced in tryptone-containing media. Final acetate concentrations were comparable to those reported previously for Pyrococcus
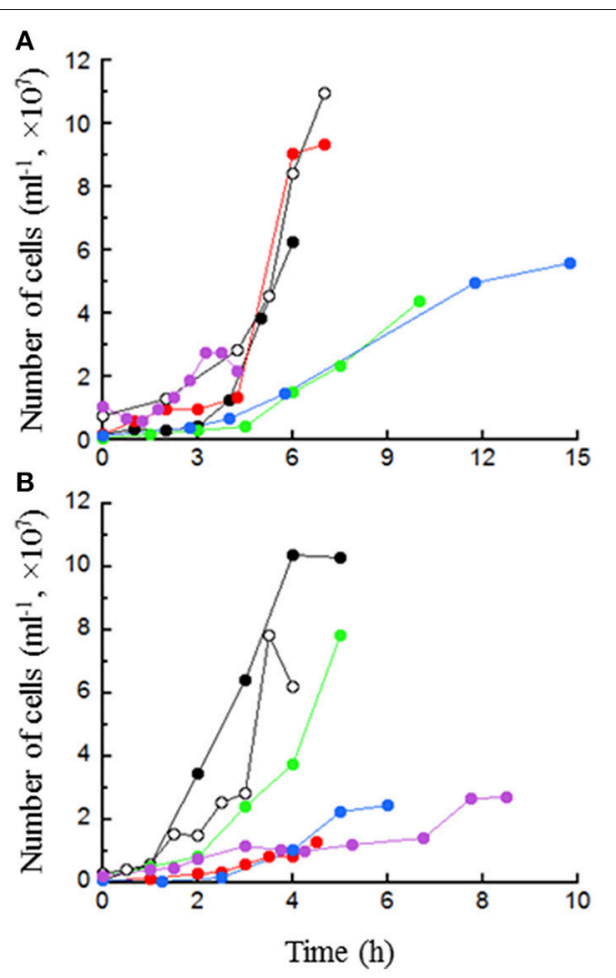

FIGURE 6 | Growth of T. paralvinellae (A) and P. furiosus (B) in the 20-I bioreactor in $0.5 \%$ maltose $(\bullet), 0.5 \%$ tryptone $(\odot), 0.5 \%$ maltose + $0.05 \%$ tryptone (०), $0.5 \%$ maltose $+10 \mathrm{mM}$ acetate $(0), 0.5 \%$ maltose at pH $5.0(\bullet)$, and $\mathbf{0 . 1 \%}$ waste milk (๑). Data are examples from individual bioreactor reactions.

and Thermococcus species grown in batch culture (Schäfer and Schönheit, 1992; Ma et al., 1995; Nohara et al., 2014). Alanine, ethanol, butanol, and formate are other metabolites that have been reported for various Thermococcus and Pyrococcus species when terminal electron acceptors are in limited supply or when the $\mathrm{H}_{2}$ partial pressure is elevated (Kengen and Stams, 1994; Ma et al., 1995; Nohara et al., 2014). Alcohol production and $\mathrm{ADH}$ and FDH activities increased in T. paralvinellae when it was grown on low $\left(1 \mathrm{~g} \mathrm{l}^{-1}\right)$ sulfur concentrations (Ma et al., 1995). Recently, it was shown that $P$. furiosus reduces acetate and other carboxylic acids first to an aldehyde by AOR and then to an alcohol when a recombinant $a d h \mathrm{~A}$ gene is introduced into the organism's genome (Basen et al., 2014). The genomes of T. paralvinellae and $P$. furiosus contain four and two adhA genes, respectively (Robb et al., 2001; Jung et al., 2014), suggesting that they naturally have the ability to produce alcohols from aldehydes. However, alcohols were undetectable in this study and $\mathrm{ADH}$ activities were very low to undetectable in both organisms suggesting that alcohol production is not a significant alternative pathway for electron disposal for these organisms even in the presence of high acetate concentrations or low $\mathrm{pH}$. Formate was produced by both organisms, sometimes surpassing acetate production, but FDH activities were low in both organisms and the mechanism for its production is unknown. Formate has not been reported previously for P. furiosus, although this may be for analytical reasons since previous detection methods 
were not focused on formate. Formate has been reported as a metabolite for Thermococcus kodakarensis (Nohara et al., 2014).

\section{Growth, $\mathrm{H}_{2}$ Production Kinetics, and Enzyme Activities}

Over the past decade, food waste in the U.S. has risen to account for the largest proportion (21\%) of municipal solid waste (MSW; Staley and Barlaz, 2009; United States Environmental Protection Agency (US EPA), 2014). As of 2012, only $3 \%$ of food waste in the U.S. was treated with the rest becoming a part of MSW and buried in landfills (United States Environmental Protection Agency (US EPA), 2014). Food waste is produced at every stage of production from farms and food processing facilities as pre-consumer waste to domestic waste (Lin et al., 2013). Although the amount of waste for each sector is fairly evenly spread, waste produced by the agricultural and manufacturing sector is generated in a more concentrated manner and would therefore be easier to collect, process, and treat to keep it from entering landfills and help offset the costs of collection. Therefore, recent developments in waste management technology have focused on pre-consumer waste. Diverting food waste to composting and biological treatment is considered promising to limit landfill growth and produce biofuels (Hermann et al., 2011). Microorganisms that catabolize long-chain carbohydrates and polypeptides and produce an energy product such as $\mathrm{H}_{2}, \mathrm{CH}_{4}$, and alcohols are ideal for these processes (Angenent et al., 2004; Alper and Stephanopoulos, 2009). This study showed that T. paralvinellae and P. furiosus grew and produced $\mathrm{H}_{2}$ on waste milk from cows treated with Ceftiofur and from healthy untreated cows and spent brewery grain. T. paralvinellae produced more $\mathrm{H}_{2}$ and grew on higher feedstock concentrations relative to $P$. furiosus, but generally grew slower than $P$. furiosus on the wastes.

Waste milk from dairy farms and cows being treated for mastitis (a commonly occurring infection and inflammation of utters) with the bacterial antibiotic Ceftiofur is particularly problematic. Cows undergoing treatment need to be milked daily and produce $\sim 37 \mathrm{~L}$ of milk per cow per day. While only $0.1 \%$ of the initial antibiotic dose is excreted in milk, the milk cannot be added to the food supply for 5 days after treatment (Hornish and Kotarski, 2002). The U.S Food and Drug Administration requires that the concentration of Ceftiofur in waste milk be less than $50 \mathrm{ppb}$ before disposal (Samanidou and Nisyriou, 2008). Because of the antibiotic, waste milk cannot be disposed of with MSW or sewage, nor should it be mixed with manure and spread onto fields as fertilizer due to increasing antibiotic resistance in nature. The waste milk is often pasteurized and fed to calves; however, resistance of calf gut bacteria to antibiotics was shown to increase in calves fed milk with increasing concentrations of antibiotics (Langford et al., 2003). Therefore, an alternative waste disposal mechanism is needed. Ceftiofur is a $\beta$-lactam that inhibits peptidoglycan synthesis and thus does not affect Thermococcus and Pyrococcus since they are archaea. In this study, there was no change in either growth rate or $\mathrm{H}_{2}$ production for either T. paralvinellae or P. furiosus when they were grown on milk from Ceftiofur-treated cows relative to milk from untreated cows indicating that the antibiotic was ineffective against them.
Furthermore, the half-life of Ceftiofur at $67^{\circ} \mathrm{C}$ is $6 \mathrm{~h}$, which decreases with increasing temperature (Sunkara et al., 1999). In our study, the concentration of Ceftiofur after $1 \mathrm{~h}$ of incubation at $82^{\circ} \mathrm{C}$, with and without $T$. paralvinellae, was below the detection limit ( $2 \mathrm{ppb})$.

Raw bovine milk contains by weight $3 \%$ protein (mostly casein), $4 \%$ fat, and 5\% carbohydrate (mostly lactose; Wong et al., 1988). The solids in spent brewery grain are mostly carbohydrate (starch). In this study, T. paralvinellae and $P$. furiosus grew fastest and produced the most $\mathrm{H}_{2}$ on media containing a combination of carbohydrate and peptides. Soluble protein was removed from the milk by the organisms, but neither organism grew on lactose or removed it from the milk. They both possess genes for a $\beta$-galactosidase (Robb et al., 2001; Jung et al., 2014), for which the recombinant version of the enzyme from $P$. furiosus cleaved lactose (Dong et al., 2014). They also grow on cellobiose (Oslowski et al., 2011), which chemically is similar to lactose, suggesting that they might be adaptable to growth on lactose as well.

The only previous study to examine agricultural waste degradation linked with $\mathrm{H}_{2}$ production by a hyperthermophile was a two-stage process for keratin degradation. In the first stage, a Bacillus species was used to aerobically degrade feather waste into a keratin hydrolysate, which was then used in the second stage as a feedstock for $\mathrm{H}_{2}$ production by Thermococccus litoralis (Bálint et al., 2005). T. litoralis produced up to $3 \mathrm{mmol}$ $\mathrm{L}^{-1}$ of $\mathrm{H}_{2}$ on that feedstock. Genetically modified $T$. onnurineus converted the $\mathrm{CO}$ in steel industry syngas into $\mathrm{H}_{2}$ three times faster than wild-type cells at rates up to $60 \mathrm{mmol} \mathrm{L}^{-1} \mathrm{~h}^{-1}$ demonstrating the potential for enhancing waste conversion rates through genetic engineering (Kim et al., 2013). In this study, T. paralvinellae degraded waste milk and spent brewery grain in a single consolidated processing step. The heat from the incubation eliminated the pathogens present and degraded the heat-labile antibiotic present in the waste milk. T. paralvinellae produced increasing amounts of $\mathrm{H}_{2}$ from both agricultural wastes types with increasing concentration. It also grows over a lower temperature range than $P$. furiosus, which may give T. paralvinellae a cost advantage over $P$. furiosus due to lower reactor heating costs. Therefore, it may be feasible to use $T$. paralvinellae, or a similar hyperthermophilic heterotroph, for rapid, mesoscale treatment of organic wastes to reduce the organic load, generate $\mathrm{H}_{2}$ as an energy byproduct, and remove pathogens.

\section{AUTHOR CONTRIBUTIONS}

All authors listed, have made substantial, direct and intellectual contribution to the work, and approved it for publication.

\section{ACKNOWLEDGMENTS}

We thank Dr. Kyunghwa Baek, Dr. Cheon-Seok Park, Marie Kroeger, Begüm Topçuoğlu, Samantha Zelin, Katarina Olsson Gudmundsson, Alexander Basu, Dr. Michael Levine, and the lab of Dr. Jeffrey Blanchard for their assistance with experiments and data analysis; Dr. Kristen DeAngelis and Dr. Caitlyn Butler for 
their comments on the manuscript; and the Amherst Brewing Company and Barstow Family Farms for providing spent brewery grain and waste milk. This work was supported by grants to $\mathrm{JH}$ from the Northeast Sun Grant Institute of Excellence (NE11-26), USDA CSREES (MAS00431), and the Gordon and Betty Moore Foundation (GBMF 3297).

\section{REFERENCES}

Adams, M. W. W. (1999). The biochemical diversity of life near and above $100^{\circ} \mathrm{C}$ in marine environments. J. Appl. Microbiol. 85, 108S-117S. doi: 10.1111/j.13652672.1998.tb05289.x

Adams, M. W. W., Holden, J. F., Menon, A. L., Schut, G. J., Grunden, A. M., Hou, C., et al. (2001). Key role for sulfur in peptide metabolism and in regulation of three hydrogenases in the hyperthermophilic archaeon Pyrococcus furiosus. J. Bacteriol. 183, 716-724. doi: 10.1128/JB.183.2.716-724.2001

Alper, H., and Stephanopoulos, G. (2009). Engineering for biofuels: exploiting innate microbial capacity or importing biosynthetic potential? Nat. Rev. Microbiol. 7, 715-723. doi: 10.1038/nrmicro2186

Angenent, L. T., Karim, K., Al-Dahhan, M. H., Wrenn, B. A., and DomíguezEspinosa, R. (2004). Production of bioenergy and biochemical from industrial and agricultural wastewater. Trends Biotechnol. 22, 477-485. doi: 10.1016/j.tibtech.2004.07.001

Bae, S. S., Kim, T. W., Lee, H. S., Kwon, K. K., Kim, Y. J., Kim, M. S., et al. (2012). $\mathrm{H}_{2}$ production from $\mathrm{CO}$, formate or starch using the hyperthermophilic archaeon, Thermococcus onnurineus. Biotechnol. Lett. 34, 75-79. doi: 10.1007/s10529-0110732-3

Bálint, B., Bagi, Z., Tóth, A., Rákhely, G., Perei, K., and Kovács, K. L. (2005). Utilization of keratin-containing biowaste to produce biohydrogen. Appl. Microbiol. Biotechnol. 69, 404-410. doi: 10.1007/s00253-0051993-3

Basen, M., Schut, G. J., Nguyen, D. M., Lipscomb, G. L., Benn, R. A., Prybol, C. J., et al. (2014). Single gene insertion drives bioalcohol production by a thermophilic archaeon. Proc. Natl. Acad. Sci. U.S.A. 111, 17618-17623. doi: 10.1073/pnas.1413789111

Blamey, J. M., and Adams, M. W. W. (1993). Purification and characterization of pyruvate ferredoxin oxidoreductase from the hyperthermophilic archaeon Pyrococcus furiosus. Biochim. Biophys. Acta 1161, 19-27. doi: 10.1016/01674838(93)90190-3

Bonch-Osmolovskaya, E. A., and Stetter, K. O. (1991). Interspecies hydrogen transfer in cocultures of thermophilic Archaea. Syst. Appl. Microbiol. 14, 205-208. doi: 10.1016/S0723-2020(11)80369-3

Bougrier, C., Battimelli, A., Delgenes, J. P., and Carrere, H. (2007). Combined ozone pretreatment and anaerobic digestion for the reduction of biological sludge production in wastewater treatment. Ozone Sci. Eng. 29, 201-206. doi: 10.1080/01919510701296754

Bräsen, C., and Schönheit, P. (2004). Unusual ADP-forming acetyl-coenzyme A synthetases from the mesophilic halophilic euryarchaeon Haloarcula marismortui and from the hyperthermophilic crenarchaeon Pyrobaculum aerophilum. FEBS Lett. 579, 477-482. doi: 10.1016/j.febslet.2004.12.016

Bryant, F. O., and Adams, M. W. W. (1989). Characterization of hydrogenase from the hyperthermophilic archaebacterium, Pyrococcus furiosus. J. Biol. Chem. 264, 5070-5079.

Canganella, F., and Jones, W. J. (1994). Fermentation studies with thermophilic Archaea in pure culture and in syntrophy with a thermophilic methanogen. Curr. Microbiol. 28, 293-298. doi: 10.1007/BF01573209

Dabrock, B., Bahl, H., and Gottschalk, G. (1992). Parameters affecting solvent production by Clostridium pasteurium. Appl. Environ. Microbiol. 58, 1233-1239.

Davidova, I. A., Duncan, K. E., Perez-Ibarra, B. M., and Suflita, J. M. (2012). Involvement of thermophilic archaea in the biocorrosion of oil pipelines. Environ. Microbiol. 14, 1762-1771. doi: 10.1111/j.1462-2920.2012.02721.x

Diggelman, C., and Ham, R. K. (2003). Household food waste to wastewater or to solid waste? That is the question. Waste Manage. Res. 21, 501-514. doi: 10.1177/0734242X0302100603

Dong, Q., Yan, X., Zheng, M., and Yang, Z. (2014). Characterization of an extremely thermostable but cold-adaptive $\beta$-galactosidase from the hyperthermophilic archaeon Pyrococcus furiosus for use as a recombinant aggregation for batch

lactose degradation at high temperature. J. Biosci. Bioeng. 117, 706-710. doi: 10.1016/j.jbiosc.2013.12.002

Girguis, P. R., and Holden, J. F. (2012). On the potential for bioenergy and biofuels from hydrothermal vent microbes. Oceanography 25, 213-217. doi: 10.5670/oceanog.2012.20

Heider, J., Mai, J., and Adams, M. W. W. (1996). Characterization of 2 ketoisovalerate ferredoxin oxidoreductase, a new and reversible coenzyme Adependent enzyme involved in peptide fermentation by hyperthermophilic archaea. J. Bacteriol. 178, 780-787.

Heinonen, J. E., and Lahti, R. J. (1981). A new and convenient colorimetric determination of inorganic orthophosphate and its application to the assay of inorganic pyrophosphatase. Anal. Biochem. 113, 313-317. doi: 10.1016/00032697(81)90082-8

Hensley, S. A., Jung, J. H., Park, C. S., and Holden, J. F. (2014). Thermococcus paralvinellae sp. nov. and Thermococcus cleftensis sp. nov., new species of hyperthermophilic heterotrophs from deep-sea hydrothermal vents. Int. J. Syst. Evol. Microbiol. 64, 3655-3659. doi: 10.1099/ijs.0.066100-0

Hermann, B. G., Debeer, L., de Wilde, B., Blok, K., and Patel, M. K. (2011). To compost or not to compost: carbon and energy footprints of biodegradable materials' waste treatment. Polym. Degrad. Stab. 96, 1159-1171. doi: 10.1016/j.polymdegradstab.2010.12.026

Hornish, R. E., and Kotarski, S. F. (2002). Cephalosporins in veterinary medicine: ceftiofur use in food animals. Curr. Top. Med. Chem. 2, 717-731. doi: $10.2174 / 1568026023393679$

Jung, J. H., Kim, Y. T., Jeon, E. J., Seo, D. H., Hensley, S. A., Holden, J. F., et al. (2014). Complete genome sequence of hyperthermophilic archaeon Thermococcus sp. ES1. J. Biotechnol. 174, 14-15. doi: 10.1016/j.jbiotec.2014.01.022

Kanai, T., Imanaka, H., Nakajima, A., Uwamori, K., Omori, Y., Fukui, T., et al. (2005). Continuous hydrogen production by the hyperthermophilic archaeon, Thermococcus kodakaraensis KOD1. J. Biotechnol. 116, 271-282. doi: 10.1016/j.jbiotec.2004.11.002

Kengen, S. W., de Bok, F. A., van Loo, N. D., Dijkema, C., Stams, A. J., and de Vos, W. M. (1994). Evidence for the operation of a novel Embden-Meyerhof pathway that involves ADP-dependent kinases during sugar fermentation by Pyrococcus furiosus. J. Biol. Chem. 269, 17537-17541.

Kengen, S. W. M., and Stams, A. J. M. (1994). Formation of L-alanine as a reduced end product in carbohydrate fermentation by the hyperthermophilic archaeon Pyrococcus furiosus. Arch. Microbiol. 161, 168-175. doi: 10.1007/BF00276479

Kim, M. S., Bae, S. S., Kim, Y. J., Kim, T. W., Lim, J. K., Lee, S. H., et al. (2013). COdependent $\mathrm{H}_{2}$ production by genetically engineered Thermococcus onnurineus NA1. Appl. Environ. Microbiol. 9, 2048-2053. doi: 10.1128/AEM.03298-12

Kim, S. H., Han, S. K., and Shin, H. S. (2004). Feasibility of biohydrogen production by anaerobic co-digestion of food waste and sewage sludge. Int. J. Hydrogen Energy 29, 1607-1216. doi: 10.1016/j.ijhydene.2004.02.018

Kim, Y. J., Lee, H. S., Kim, E. S., Bae, S. S., Lim, J. K., Matsumi, R., et al. (2010). Formate-driven growth coupled with $\mathrm{H}_{2}$ production. Nature 467, 352-355. doi: 10.1038/nature09375

Krahe, M., Antranikian, G., and Märkl, H. (1996). Fermentation of extremophilic microorganisms. FEMS Microbiol. Rev. 18, 271-285. doi: 10.1111/j.15746976.1996.tb00243.x

Lai, C. M., Ke, G. R., and Chung, M. Y. (2009). Potentials of food wastes for power generation and energy conservation in Taiwan. Renew. Energy 34, 1913-1915. doi: 10.1016/j.renene.2008.12.007

Langford, F. M., Weary, D. M., and Fisher, L. (2003). Antibiotic resistance in gut bacteria from dairy calves: a dose response to the level of antibiotics fed in milk. J. Dairy Sci. 86, 3963-3966. doi: 10.3168/jds.S0022-0302(03)74006-5

Lee, S. H., Choi, K. I., Osako, M., and Dong, J. I. (2007). Evaluation of environmental burdens caused by changes of food waste management systems in Seoul, Korea. Sci. Total Environ. 387, 42-53. doi: 10.1016/j.scitotenv.2007.06.037 
Levis, J. W., Barlaz, M. A., Themelis, N. J., and Ulloa, P. (2010). Assessment of the state of food waste treatment in the United States and Canada. Waste Manag. 30, 1486-1494. doi: 10.1016/j.wasman.2010.01.031

Lin, C. S. K., Pfaltzgraff, L. A., Herrero-Davila, L., Mudofu, E. B., Abderrahim, S., Clark, J. H., et al. (2013). Food waste as a valuable resource for the production of chemicals, materials and fuels: current situation and global perspective. Energy Environ. Sci. 6, 426-464. doi: 10.1039/c2ee23440h

Ma, K., and Adams, M. W. W. (1994). Sulfide dehydrogenase from the hyperthermophilic archaeon Pyrococcus furiosus: a new multifunctional enzyme involved in the reduction of elemental sulfur. J. Bacteriol. 176, 6509-6517.

Ma, K., and Adams, M. W. W. (1999). An unusual oxygen-sensitive, iron- and zinc-containing alcohol dehydrogenase from the hyperthermophilic archaeon Pyrococcus furiosus. J. Bacteriol. 181, 1163-1170.

Ma, K., Loessner, H., Heider, J., Johnson, M. K., and Adams, M. W. W. (1995). Effects of elemental sulfur on the metabolism of the deep-sea hyperthermophilic archaeon Thermococcus strain ES-1: characterization of a sulfur-regulated, non-heme iron alcohol dehydrogenase. J. Bacteriol. 177, 4748-4756.

Ma, K., Weiss, R., and Adams, M. W. W. (2000). Characterization of hydrogenase II from the hyperthermophilic archaeon Pyrococcus furiosus and assessment of its role in sulfur reduction. J. Bacteriol. 182, 1864-1871. doi: 10.1128/JB.182.7.1864-1871.2000

Mai, X., and Adams, M. W. W. (1996). Purification and characterization of two reversible acyl-CoA synthetases (ADP-forming) from the hyperthermophilic archaeon Pyrococcus furiosus. J. Bacteriol. 178, 5897-5903.

Mukund, S., and Adams, M. W. W. (1991). The novel tungsten-iron-sulfur protein of the hyperthermophilic archaebacterium, Pyrococcus furiosus, is an aldehyde ferredoxin oxidoreductase. J. Biol. Chem. 266, 14208-14216.

Mukund, S., and Adams, M. W. W. (1995). Glyceraldehyde-3-phosphate ferredoxin oxidoreductase, a novel tungsten-containing enzyme with a potential glycolytic role in the hyperthermophilic archaeon Pyrococcus furiosus. J. Biol. Chem. 270, 8389-8392. doi: 10.1074/jbc.270.15.8389

Nohara, K., Orita, I., Nakamura, S., Imanaka, T., and Fukui, T. (2014). Genetic examination and mass balance analysis of pyruvate/amino acid oxidation pathways in the hyperthermophilic archaeon Thermococcus kodakarensis. J. Bacteriol. 196, 3831-3839. doi: 10.1128/JB.02021-14

Ntaikou, I., Antonopoulou, G., and Lyberatos, G. (2010). Biohydrogen production from biomass and wastes via dark fermentation: a review. Waste Biomass Valorization 1, 21-39. doi: 10.1007/s12649-009-9001-2

Oslowski, D. M., Jung, J. H., Seo, D. H., Park, C. S., and Holden, J. F. (2011). Production of hydrogen from $\alpha$-1,4- and $\beta$-1,4-linked saccharides by marine hyperthermophilic archaea. Appl. Environ. Microbiol. 77, 3169-3173. doi: 10.1128/AEM.01366-10

Pawar, S. S., and van Niel, E. W. J. (2013). Thermophilic biohydrogen production: how far are we? Appl. Microbiol. Biotechnol. 97, 7999-8009. doi: 10.1007/s00253-013-5141-1

Pisa, K. Y., Huber, H., Thomm, M., and Müller, V. (2007). A sodium ion-dependent $\mathrm{A}_{1} \mathrm{~A}_{0}$ ATP synthase from the hyperthermophilic archaeon Pyrococcus furiosus. FEBS J. 274, 3928-3938. doi: 10.1111/j.1742-4658.2007.05925.x

Pledger, R. J., and Baross, J. A. (1989). Characterization of an extremely thermophilic archaebacterium isolated from a black smoker polychaete (Paralvinella sp.) at the Juan de Fuca Ridge. Syst. Appl. Microbiol. 12, 249-256. doi: 10.1016/S0723-2020(89)80070-0

R Core Team (2013). R: A Language and Environment for Statistical Computing. Vienna: R Foundation for Statistical Computing. ISBN 3-900051-07-0. Available online at: http://www.R-project.org.

Robb, F. T., Maeder, D. L., Brown, J. R., DiRuggiero, J., Stump, M. D., Yeh, R. K., et al. (2001). Genomic sequence of hyperthermophile, Pyrococcus furiosus: implications for physiology and enzymology. Methods Enzymol. 330, 134-157. doi: 10.1016/S0076-6879(01)30372-5

Robb, F. T., Park, J. B., and Adams, M. W. W. (1992). Characterization of an extremely thermostable glutamate dehydrogenase: a key enzyme in the primary metabolism of the hyperthermophilic archaebacterium, Pyrococcus furiosus Biochim. Biophys. Acta 1120, 267-272. doi: 10.1016/0167-4838(92)90247-B

Roy, R., Mukund, S., Schut, G. J., Dunn, D. M., Weiss, R., and Adams, M. W. W. (1999). Purification and molecular characterization of the tungsten-containing formaldehyde ferredoxin oxidoreductase from the hyperthermophilic archaeon Pyrococcus furiosus: the third of a putative five-member tungstoenzyme family. J. Bacteriol. 181, 1171-1180.

Samanidou, V., and Nisyriou, S. (2008). Multi-residue methods for confirmatory determination of antibiotics in milk. J. Sep. Sci. 31, 2068-2090. doi: $10.1002 /$ jssc. 200700647

Sapra, R., Verhagen, M. F. J. M., and Adams, M. W. W. (2000). Purification and characterization of a membrane-bound hydrogenase from the hyperthermophilic archaeon Pyrococcus furiosus. J. Bacteriol. 182, 3423-3428. doi: 10.1128/JB.182.12.3423-3428.2000

Schäfer, T., and Schönheit, P. (1992). Maltose fermentation to acetate, $\mathrm{CO}_{2}$ and $\mathrm{H}_{2}$ in the anaerobic hyperthermophilic archaeon Pyrococcus furiosus: evidence for the operation of a novel sugar fermentation pathway. Arch. Microbiol. 158, 188-202. doi: 10.1007/BF00290815

Schäfer, T., Selig, M., and Schönheit, P. (1993). Acetyl-CoA synthetase (ADP-forming) in archaea, a novel enzyme involved in acetate formation and ATP synthesis. Arch. Microbiol. 159, 72-83. doi: 10.1007/BF00 244267

Schut, G. J., Brehm, S. D., Datta, S., and Adams, M. W. W. (2003). Whole-genome DNA microarray analysis of a hyperthermophile and an archaeon: Pyrococcus furiosus grown on carbohydrates or peptides. J. Bacteriol. 185, 3935-3947. doi: 10.1128/JB.185.13.3935-3947.2003

Staley, B. F., and Barlaz, M. A. (2009). Composition of municipal solid waste in the US and implications for carbon sequestration and methane yield. J. Environ. Eng. 135, 901-909. doi: 10.1061/(ASCE)EE.1943-7870.0000032

Sunkara, G., Navarre, C. B., and Kompella, U. B. (1999). Influence of pH and temperature on kinetics of Ceftiofur degradation in aqueous solutions. J. Pharm. Pharmacol. 51, 249-255. doi: 10.1211/0022357991772411

United States Environmental Protection Agency (US EPA). (2014). Municipal Solid Waste Generation, Recycling, and Disposal in the United States: Facts and Figures for 2012. EPA-530-F-14-001, Washington, DC.

Ver Eecke, H. C., Butterfield, D. A., Huber, J. A., Lilley, M. D., Olson, E. J., Roe, K. K., et al. (2012). Hydrogen-limited growth of hyperthermophilic methanogens at deep-sea hydrothermal vents. Proc. Natl. Acad. Sci. U.S.A. 109, 13674-13679. doi: 10.1073/pnas.1206632109

Verhees, C. H., Kengen, S. W. M., Tuininga, J. E., Schut, G. J., Adams, M. W. W., de Vos, W. M., et al. (2003). The unique features of glycolytic pathways in Archaea. Biochem. J. 375, 231-246. doi: 10.1042/bj20021472

Wang, J., and Wan, W. (2009). Experimental design methods for fermentative hydrogen production: a review. Int. J. Hydrogen Energy 34, 235-244. doi: 10.1016/j.ijhydene.2008.10.008

Ward, D. E., Kengen, S. W. M., van der Oost, J., and de Vos, W. M. (2000). Purification and characterization of the alanine aminotransferase from the hyperthermophilic archaeon Pyrococcus furiosus and its role in alanine production. J. Bacteriol. 182, 2559-2566. doi: 10.1128/JB.182.9.2559-25 66.2000

Wong, N. P., Jenness, R., Keeney, M., and Marth, E. H. (1988). Fundamentals of Dairy Chemistry, 3rd Edn. New York, NY: Van Nostrand Reinhold.

Conflict of Interest Statement: The authors declare that the research was conducted in the absence of any commercial or financial relationships that could be construed as a potential conflict of interest.

Copyright (c) 2016 Hensley, Moreira and Holden. This is an open-access article distributed under the terms of the Creative Commons Attribution License (CC BY). The use, distribution or reproduction in other forums is permitted, provided the original author(s) or licensor are credited and that the original publication in this journal is cited, in accordance with accepted academic practice. No use, distribution or reproduction is permitted which does not comply with these terms. 